\title{
Decolourisations and biodegradations of model azo dye solutions using a sequence batch reactor, followed by ultrafiltration
}

Korenak, J.; Ploder, J.; Trek, J.; Hélix-Nielsen, Claus; Petrinic, I.

Published in:

International Journal of Environmental Science and Technology

Link to article, DOI:

10.1007/s13762-017-1406-z

Publication date:

2018

Document Version

Peer reviewed version

Link back to DTU Orbit

Citation (APA):

Korenak, J., Ploder, J., Trek, J., Hélix-Nielsen, C., \& Petrinic, I. (2018). Decolourisations and biodegradations of model azo dye solutions using a sequence batch reactor, followed by ultrafiltration. International Journal of Environmental Science and Technology, 15(3), 483-492. https://doi.org/10.1007/s13762-017-1406-z

\section{General rights}

Copyright and moral rights for the publications made accessible in the public portal are retained by the authors and/or other copyright owners and it is a condition of accessing publications that users recognise and abide by the legal requirements associated with these rights.

- Users may download and print one copy of any publication from the public portal for the purpose of private study or research.

- You may not further distribute the material or use it for any profit-making activity or commercial gain

- You may freely distribute the URL identifying the publication in the public portal 


\section{International Journal of Environmental Science and Technology DECOLOURISATIONS AND BIODEGRADATIONS OF MODEL AZO DYE SOLUTIONS USING A SEQUENCE BATCH REACTOR, FOLLOWED BY ULTRAFILTRATION \\ --Manuscript Draft--}

Manuscript Number:

Full Title:
JEST-D-16-00404R1

DECOLOURISATIONS AND BIODEGRADATIONS OF MODEL AZO DYE SOLUTIONS USING A SEQUENCE BATCH REACTOR, FOLLOWED BY ULTRAFILTRATION

Short Title: DECOLOURISATION AND BIODEGRADATION OF A MODEL AZO DYE SOLUTION

Article Type:

Original Paper

Keywords:

Azo dye wastewater; Decolourisation; Microbial characterisation; Sequencing batch reactor; ultrafiltration

\section{Corresponding Author:}

Jasmina Korenak

University of Maribor

SLOVENIA

Corresponding Author Secondary

Information:

Corresponding Author's Institution:

University of Maribor

Corresponding Author's Secondary Institution:

First Author:

Jasmina Korenak

First Author Secondary Information:

Order of Authors:

Jasmina Korenak

Jana Ploder

Janja Trcek

Claus Helix-Nielsen

Irena Petrinic

Order of Authors Secondary Information:

Funding Information:

EraSME

$(430-26 / 2010 / 40)$

Dr Irena Petrinic

\section{Abstract:}

The main objective of this study was to investigate the efficiency of biological treatment of azo dye-containing wastewater with a sequencing batch reactor system, followed by ultrafiltration. The performance of the system was quantified by measuring the chemical oxygen demand and azo dye concentration. The biodegradation was carried out under combined alternating anaerobic and aerobic conditions with Nylosan yellow E2RL SGR as a model azo dye contaminant. The bioprocess revealed a maximal reduction of chemical oxygen demand and dye removal efficiency of $91 \%$ and $85 \%$, respectively. After ultrafiltration of effluent from the biological treatment, the efficiency increased to $94 \%$ for chemical oxygen demand and to $97 \%$ for the azo dye decolourisation. Samples of activated sludge from the bioprocess were collected for microbial characterisation. Bacteria and fungi were isolated and identified by 16S rRNA gene and ITS1-5.8S rDNA-ITS2 sequence analysis, respectively. Serratia marcescens and Klebsiella oxytoca were the most common bacteria with the highest number present during the aerobic and anaerobic phases of the bioprocess. In addition, a high number of Elizabethkingia miricola, Morganella morganii, Comamonas testosterone, Trichosporon sp. and Galactomyces sp. were detected. Taken together, our results demonstrated that the sequencing batch reactor system combined with ultrafiltration is an efficient technique for treatment of wastewater containing azo dye. Moreover, the ultrafiltration effectively removes the microbiota from the final effluent resulting in stable 
product water.

Powered by Editorial Manager ${ }^{\circledR}$ and ProduXion Manager ${ }^{\circledR}$ from Aries Systems Corporation 


\section{Author Query Form}

\begin{tabular}{|c|c|}
\hline \multicolumn{2}{|l|}{ Author Query Form } \\
\hline Reviewers \#1 comments & Author(s) response* \\
\hline $\begin{array}{l}\text { Comments to "Inactivation of } \\
\text { Escherichia coli Planktonic Cells by } \\
\text { Multi-walled Carbon Nanotubes in } \\
\text { Suspensions: Effect of Surface } \\
\text { Functionalization Coupled with } \\
\text { Medium Nutrition Level" }\end{array}$ & $\begin{array}{r}\text { The reviewer \#1 provided a } \\
\text { comments for an article titled } \\
\text { "Inactivation of Escherichia coli } \\
\text { Planktonic Cells by Multi-walled } \\
\text { Carbon Nanotubes in Suspensions: } \\
\text { Effect of Surface Functionalization } \\
\text { Coupled with Medium Nutrition } \\
\text { Level" and has been sent to us. } \\
\text { Therefore, the comments are not } \\
\text { relevant for our article titled } \\
\text { "DECOLOURISATIONS AND } \\
\text { BIODEGRADATIONS OF } \\
\text { MODEL AZO DYE SOLUTIONS } \\
\text { USING A SEQUENCE BATCH } \\
\text { REACTOR, FOLLOWED BY } \\
\text { ULTRAFILTRATION " }\end{array}$ \\
\hline
\end{tabular}




\section{$\underline{\text { Author Query Form }}$}

\begin{tabular}{|c|c|}
\hline \multicolumn{2}{|l|}{ Author Query Form } \\
\hline Reviewers \#2 comments & Author(s) response* \\
\hline \multicolumn{2}{|l|}{ Introduction: } \\
\hline $\begin{array}{r}\text { 1. Page } 4 \text {, line } 3 \text {, it should be "for } \\
\text { color removal" or "for dye } \\
\text { degradation". }\end{array}$ & $\begin{array}{r}\text { Corrected } \\
\text { Please see page } 4 \text {, line } 3 .\end{array}$ \\
\hline $\begin{array}{l}\text { 2. Page 4, line 8, "Cinar et al", not "at } \\
\text { al". }\end{array}$ & $\begin{array}{r}\text { Corrected } \\
\text { Please see page } 4 \text {, line } 7 .\end{array}$ \\
\hline $\begin{array}{r}\text { 3. Page } 4 \text {, line } 8-15 \text {, add a blank } \\
\text { between } 24 \text { and hour, and check the } \\
\text { whole manuscript please. }\end{array}$ & $\begin{array}{r}\text { Corrected } \\
\text { Please see whole manuscript. }\end{array}$ \\
\hline \multicolumn{2}{|l|}{ Materials and methods: } \\
\hline $\begin{array}{r}\text { Page 4, line 41, check the } \\
\text { unit please. }\end{array}$ & $\begin{array}{r}\text { Corrected } \\
\text { Please see page 4, line } 30,31\end{array}$ \\
\hline \multicolumn{2}{|l|}{ Results and discussion: } \\
\hline $\begin{array}{l}\text { Page } 6 \text {, line } 46 \text {, check the } \\
\text { first sentence please. }\end{array}$ & $\begin{array}{r}\text { Corrected } \\
\text { Please see page 6, line } 20,21\end{array}$ \\
\hline $\begin{array}{l}\text { Page } 7 \text {, line } 8 \text {, it should be } \\
\text { "dye degradation". }\end{array}$ & $\begin{array}{r}\text { Corrected } \\
\text { Please see page } 6 \text {, line } 25\end{array}$ \\
\hline $\begin{array}{c}\text { 3. Page } 7 \text {, line } 17 \text {, check } \\
\text { "determine the SBR process" please. }\end{array}$ & $\begin{array}{r}\text { Corrected } \\
\text { Please see page 6, line 30, } 31\end{array}$ \\
\hline
\end{tabular}




\begin{tabular}{|c|c|}
\hline $\begin{array}{l}4 . \quad \text { Actually, I'm interested in } \\
\text { the re-coloration process. Is it still } \\
\text { toxic? Can you do more experiments } \\
\text { to prove it? Because we know the } \\
\text { degradation products of azo dye under } \\
\text { anaerobic condition are more toxic } \\
\text { than azo dyes. And will any method } \\
\text { solve it? }\end{array}$ & $\begin{array}{r}\text { The reductive cleavage of azo } \\
\text { compounds to aromatic amines needs } \\
\text { anaerobic conditions and then } \\
\text { bacterial biodegradation of the } \\
\text { aromatic amines is aerobic process. } \\
\text { Therefore, a combined anaerobic- } \\
\text { aerobic bacterial process is most } \\
\text { effective. } \\
\text { Unfortunately, currently we are not } \\
\text { able to do some more tests regarding } \\
\text { this to proof the detoxified effluent. }\end{array}$ \\
\hline $\begin{array}{r}\text { Page 9, line 33, check "per } \\
\text { se" please. }\end{array}$ & $\begin{array}{r}\text { Corrected } \\
\text { Please see page } 8 \text {, line } 32\end{array}$ \\
\hline $\begin{array}{r}\text { Error bars need to be added } \\
\text { to all figures. }\end{array}$ & $\begin{array}{c}\text { Error bars are added } \\
\text { Please see Fig. } 2-6 .\end{array}$ \\
\hline
\end{tabular}




\title{
DECOLOURISATIONS AND BIODEGRADATIONS OF MODEL AZO DYE SOLUTIONS USING A SEQUENCE BATCH REACTOR, FOLLOWED BY ULTRAFILTRATION
}

\section{DECOLOURISATION AND BIODEGRADATION OF A MODEL AZO DYE SOLUTION}

\author{
Jasmina Korenak ${ }^{1}$, Jana Ploder ${ }^{2}$, Janja Trček ${ }^{1,2}$, Claus Hélix-Nielsen ${ }^{1,3}$, Irena Petrinic ${ }^{1}$, \\ ${ }^{1}$ University of Maribor, Faculty of Chemistry and Chemical Engineering, Smetanova ulica 17, SI-2000 Maribor, \\ Slovenia \\ ${ }^{2}$ University of Maribor, Faculty of Natural Sciences and Mathematics, Dep. of Biology, Koroska cesta 160, SI- \\ 2000 Maribor, Slovenia \\ ${ }^{3}$ Technical University of Denmark, Department of Environmental Engineering, Bygningstorvet 115, DK2800 \\ Kgs. Lyngby, Denmark. \\ (jasmina.korenak@um.si, jana.ploder@gmail.com, janja.trcek@um.si, clhe@env.dtu.dk, irena.petrinic@um.si)
}

Corresponding author:

Address:

E-mail:

Tel:

Fax:
Jasmina Korenak

University of Maribor, Faculty of Chemistry and Chemical Engineering, Smetanova ulica 17, SI-2000 Maribor, Slovenia jasmina.korenak@um.si

$+38622294474$

+38622527 774 


\section{DECOLOURISATIONS AND BIODEGRADATIONS OF MODEL AZO DYE SOLUTIONS USING A SEQUENCE BATCH REACTOR, FOLLOWED BY ULTRAFILTRATION \\ DECOLOURISATION AND BIODEGRADATION OF A MODEL AZO DYE SOLUTION}

7

8 


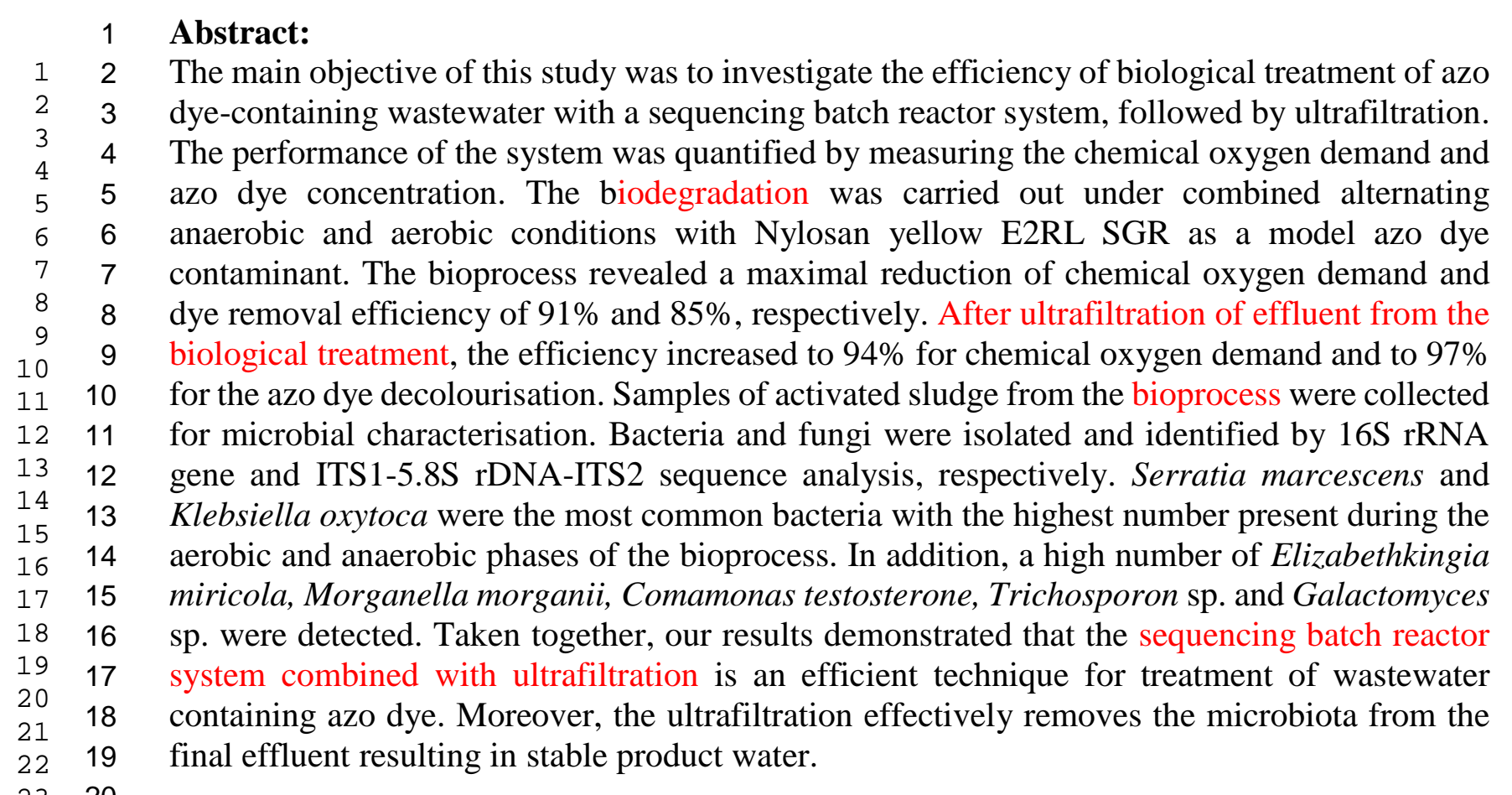

Keywords: Azo dye wastewater, Decolourisation, Microbial characterisation, Sequencing batch reactor, Ultrafiltration. 


\section{Introduction}

The textile industry is a large water consumer and overall the sector in Europe is suffering due to more stringent wastewater discharge limits, raising water costs and limited water resources. Consequently, the sector is losing competitiveness on international markets, which results in closure of companies and re-location to countries outside of Europe. Thus, in order to ensure a future competitive European textile industry there is a need to provide efficient treatment solutions for textile wastewater with final effluents that can be discharged or reused.

Raw textile wastewaters typically have a high chemical oxygen demand (COD) and contain a wide-variety of contaminants, such as salts, surfactants, soaps, enzymes, oxidizing and reducing agents and reactive dyes (Hao et al., 2000, Solís et al., 2012). Most of the coloured, high molecular-weight dye compounds are resistant to biological degradation, especially reactive dyes which can persist in the environment under natural conditions for 40 years or more (Hao et al., 2000, Brás et al., 2001, Khehra et al., 2006). Conventional biological wastewater processes can reduce COD significantly. However, these processes do not eliminate dyes. The combined ability to minimize COD and colourisation is of paramount importance in order to reuse the final effluent. Thus, a combination of different techniques is required (Hao et al., 2000).

Biotechnological treatment approaches (anaerobic or aerobic digestion or a combination of the two) for decolourising azo-containing wastewaters have been demonstrated (Saratale et al., 2011, Wu et al., 2012). Under aerobic conditions, e.g. in activated sludge systems for wastewater treatment, azo dye decolourisation can be achieved, although with low activity as oxygen is a more effective electron acceptor than the azo dyes (Chengalroyen and Dabbs, 2013). On the other hand, under anaerobic conditions, e.g. by using granular or flocculent sludges, azo dyes are generally the sole terminal electron acceptor and, because of this, a better decolourisation is obtained. The reduced products of anaerobic treatment (aromatic amines) are, in general, recalcitrant which means that complete biodegradation of azo dyes cannot be accomplished under anaerobic conditions only. However, bioconversion of these aromatic compounds under aerobic conditions is relatively quick and the reduction of azo dyes is generally regarded as a rate-limiting step in the overall biodegradation (Chen, 2006, Chengalroyen and Dabbs, 2013, Solís et al., 2012).

In microbial consortia, micro-organisms work synergistically, meaning that individual strains may degrade the dye molecule at different positions or may utilise metabolites produced by coexisting strains for further mineralisation (Chengalroyen and Dabbs, 2013). Besides, microbial cultures can have a broad spectrum for dye decolourisation due to variations in the enzymatic reactions of individual types of micro-organisms (Chengalroyen and Dabbs, 2013). It has been reported that azo dyes were almost completely decolourised by Pseudomonas sp. (Phugare et al., 2011, Jadhav et al., 2010). Some bacteria, such as Sphingomonas use the dye as a carbon source (Ayed et al., 2011), and also Geobacillus which removed efficiently dye Orange II from sewage of textile effluent (Evangelista-Barreto et al., 2009). Also other bacterial genera, such as Acetobacter, Bacillus, Xanthomonas, Morganella, Aeromonas, Klebsiella and others are reported as azo dye decolourisers (Solís et al., 2012).

Sequencing batch reactor (SBR) presents a simplistic and flexibile unit in which combined aerobic/anaerobic reactions at low costs are possible to be carried out (Al-Amrani et al., 2014, Hosseini Koupaie et al., 2011). It has been widely used in recent studies to achieve dye removal (Rajaguru et al., Lourenço et al., 2000, Sponza and Işik, 2002, Ong et al., 2005, Panswad et al., 2001) and operates by sequential stages of wastewater feeding, reactive phase (anaerobic and/or 
aerobic digestion), sedimentation, and discharge of the clarified effluent and sludge. The reactive phase can be modified during operation and adjusted to achieve optimal results for dye degradation and the removal of other contaminants. The effluent from the SBR can be then treated with ultrafiltration (UF) or nanofiltration (NF) based on demands for the effluent characteristics (Zuriaga-Agustí et al., 2010).

Çinar et al. (2008) assessed the effect of a cycle length (composed of anaerobic and aerobic phase) on decolourization of a model textile dye wastewater containing the remazol brilliant violet 5R (RBV-5R) as a model azo dye. They assessed the cycle length of 12, 24 and 48 hours in a SBR system and identified the cycle length of 24 hours (each of anaerobic and aerobic treatment proceeded for 12 hours) as optimal for dye degradation. This study did not, however, investigated the effect of anaerobic and aerobic phase length on the biodegradation, the characteristic which is an important parameter for optimization of SBR-based treatment process.

The aim of the present study was to optimize the time length of each treatment phase, aerobic and anaerobic, for maximal COD and dye removal in a lab-scale SBR-UF system using the Nylosan Yellow E2RL SGR as a model azo dye. In addition, the microbial consortium was investigated in order to identify microorganisms with the highest capabilities for colour degradation.

The study was carried out between March 2013 and March 2014, at the Faculty of Chemistry and Chemical Engineering and Faculty of Natural Sciences and Mathematics, University of Maribor, Slovenia.

\section{Materials and methods}

\subsection{Chemicals}

The azo dye (C.I. index name "acid yellow 256" and commercial name Nylosan Yellow E2RL SGR) was supplied by Clariant, (Frankfurt am Main, Germany). Nutrient Broth no 3 (SigmaAldrich) with composition of meat extract $1.0 \mathrm{~g} / \mathrm{L}$, yeast extract $2.0 \mathrm{~g} / \mathrm{L}$, peptone $5.0 \mathrm{~g} / \mathrm{L}$, and sodium chloride $5.0 \mathrm{~g} / \mathrm{L}$ was used as micro-organism nutrient. All other chemicals were analytical grade (AR) and were obtained from Sigma Aldrich or Fluka.

\subsection{Synthetic wastewater}

Synthetic textile wastewater was prepared with the azo dye, nutrient broth and D-glucose as indicated in Table 1. D-glucose was added as carbon source as azo dyes by themselves cannot provide a carbon and/or nitrogen source for micro-organisms (Sani and Banerjee, 1999, Saratale et al., 2011). 
After the process had started the micro-organisms were gradually adapted to high nutrient concentration $(13 \mathrm{~g} / \mathrm{L})$ by linearly increasing the concentration of azo dye and D-glucose until Day 21. For the remaining time these concentrations were kept constant under low nutrient conditions.

\subsection{Sequencing batch reactor system}

where $c_{i}(0)$ and $c_{i}(t)$ are the initial concentration value of component $i$ (at process start) and after reaction time $(t)$.

Initially, a 10 L SBR was seeded with $1.5 \mathrm{~L}$ of activated sludge from the municipal wastewater treatment plant (biomass concentration of $5.5 \mathrm{~g} / \mathrm{L}$ ), and $0.5 \mathrm{~L}$ of synthetic wastewater with dye concentration from 20 to $80 \mathrm{mg} / \mathrm{L}$ (see Table 1). The SBR was operated in 24 hour cycles. Each cycle comprised of periods of filling ( $5 \mathrm{~min}$ ), reaction \& settlement (total 23.5 hour), drawing (10 $\mathrm{min})$ and idling $(25 \mathrm{~min})$, where the reaction and settlement times were varied. During filling $0.5 \mathrm{~L}$ model wastewater influent was injected into the reactor at a rate of $100 \mathrm{ml} / \mathrm{min}$ and the same volume was taken during drawing for analysis. The temperature was between $22{ }^{\circ} \mathrm{C}$ and $26{ }^{\circ} \mathrm{C}$. The dissolved oxygen was between 0.02 and $0.18 \mathrm{mg} \mathrm{O} / \mathrm{L}$ and $2.7 \mathrm{mg} \mathrm{O} / \mathrm{L}$ within anaerobic and aerobic phases. Aeration was performed by an aquarium aerator (Tetra WP600, Tetra Werke, Melle, Germany) through porous stones inserted at the bottom of the reactor. The aerator was connected to a timing device allowing for control of aerobic and anoxic periods. During the entire operation (except the idling period) the reactor was stirred at $50 \mathrm{rpm}$ by magnetic stirrer.

\subsection{Ultrafiltration process}

The SBR effluent was filtered through an MN617 cellulose filter paper with 7-12 $\mu$ m retention (Macherey-Nagel, Düren, Germany) followed by filtration through an ultrafiltration UF PAN membrane (Alfa Laval, Denmark), see Table 2. The operating pressures for the filtration steps were $300-400 \mathrm{kPa}$ in dead-end configuration.

\subsection{Analytical methods}

Dyestuff colour, COD concentration, $\mathrm{pH}$, and mixed liquor suspended solids (MLSS) concentrations were measured in supernatants from samples centrifuged at $8500 \mathrm{rpm}$ for $10 \mathrm{~min}$ at $26 \pm 1{ }^{\circ} \mathrm{C}$. Nylosan yellow concentration was measured using the absorbance peak at $384 \mathrm{~nm}$ measured with a UV-vis spectrophotometer (Agilent Instrument, model 61103A, Maribor, Slovenia), see Fig. 1. Absorbance was translated into concentrations $(\mathrm{mg} / \mathrm{L})$ using a standard curve $\left(\mathrm{R}^{2}=0.998\right)$ thus allowing for determination of $c_{i}(0)$ and $c_{i}(t)$ of the dye at time 0 and $t$, respectively.

$\mathrm{pH}$ measurements were performed with a pH meter (MA 5740, Iskra, Slovenia). COD analyses were performed by the SIST ISO 6060 method with titrimetric determination and MLSS was measured according to the standard weight method (APHA, 2006).

The COD and colour removal efficiency of the process was calculated as

$$
R_{E}=\frac{c_{i(0)}-c_{i(t)}}{c_{i(0)}} \times 100 \%
$$

Eq. 1 


\subsection{Isolation and identification of microorganisms}

Samples of diluted activated sludge from anaerobic and aerobic phases of the SBR process were plated on a complex NA agar (Nutrient Agar, Sigma) containing acid dye and incubated for four days at room temperature $\left(22-26^{\circ} \mathrm{C}\right)$. The number of colonies was expressed as $\mathrm{CFU} / \mathrm{mL}$. Each type of morphologically different colonies was further purified to isolate the pure strains. The isolates were grown in liquid nutrient media, and harvested for DNA isolation by NucleoSpin Tissue kit (Macherey-Nagel, Düren, Germany). The bacterial 16S rRNA gene sequences were specifically amplified by PCR reaction using primers $16 \mathrm{SFw}$ (5'AAATTGAAGAGTTTGATCATGGC-3') and rH1542 (5'-AAGGAGGTGATCCAGCCGCA$3^{\prime}$ ) as described previously (Slapšak et al., 2013). Primers 18F1 (5'AGGTTTCCGTAGGTGAACCT-3') and ITS4 (5'- TCCTCCGCTTATTGATATGC-3') were used for amplification of the ITS1-5.8S rDNA-ITS2 fungal region as described by Štornik et al. (2016). The PCR products were cleaned by NucleoSpin Gel and PCR Clean-up kit (Macherey-Nagel, Düren, Germany) and the sequences were determined at Eurofins Genomics (Ebersberg, Germany). The sequences were analysed by Blastn (NCBI, http://blast.ncbi.nlm.nih.gov/Blast.cgi). The isolates were assigned to the genus/species to which the sequences showed the highest identity.

\section{Results and discussion}

The SBR treatment started under anaerobic conditions and followed by aerobic conditions within a treatment cycle of 24 hours, see Table 3 . The entire 24 hour treatment cycle consisted of filling, anaerobic phase, aerobic phase, settling phase, drawing phase and idling phase. The 24 hours cycle with anaerobic and aerobic phases has been used also in other studies (Lourenço et al., 2001, Kapdan and Oztekin, 2006, Hakimelahi et al., 2012). In order to optimise the SBR process for optimal dye degradation and removal of other contaminants, a total of 100 days of SBR operation was divided into three periods, designated A, B and C. For each of the periods the time length of anaerobic and aerobic phases varied (presented in Table 3).

\subsection{COD and colour removal efficiency in the SBR process}

$\mathrm{COD}$ and colour removal efficiency as well as increase of biomass growth and $\mathrm{pH}$ values were monitored. Samples were taken at the beginning of the reaction phase (feed), and at the end of the 24 hour cycle. Performance of the SBR process was evaluated based on measurements of the COD and dye concentration at the influent and effluent of the SBR process. The results for the 100 days of operation are shown in Figs. 2a and 2b. During the first 24 days of operation the colour removal efficiency fluctuated around $60 \%$ while the COD removal efficiency increased from 70 to $90 \%$. The removal efficiency can be compared with other studies (Kapdan and Oztekin, 2006). During this time the reactor was operated according to the period A described in Table 3. The reason for the low dye removal during period A could be microorganisms that have not yet been sufficiently adapted to the solution containing dye molecules. As dye substances are difficult to be degraded, more time is required to accumulate sufficient micro-organisms for dye degradation.

Azo dyes can be degraded by microbial consortium under anaerobic conditions. The products of these reactions are aromatic amines (Chengalroyen and Dabbs, 2013). A longer anaerobic reaction phase has been shown to result in a higher dye decolourization efficiency (Al-Amrani et al., 2014). Therefore, the anaerobic phase duration was increased from 9 to 11 hours on day 24 in an attempt to increase dye removal efficiency. Thus, the durations of aerobic and settling phases were reduced by one hour each. This operational mode is described as period B in Table 3. However, this change did not increase the colour removal efficiency significantly (Fig. 2a). 
In fact, it led to a decrease in COD removal efficiency as presented in Fig. $2 \mathrm{~b}$. After three days of lag phase, the COD removal efficiency decreased from $90 \%$ and stabilised at a value around $50 \%$ at day 40 . As the prolonged anaerobic phase did not lead to an increase in dye removal and also COD removal efficiency was reduced, the SBR operating conditions was changed at day 58 by reducing the anaerobic phase to 9 hours, increasing the aerobic phase to 13 hours and keeping the settling phase at 1.5 hours (presented as period $\mathrm{C}$ in Table 3 ). This resulted in colour removal at around $80 \%$ during the remaining experimental period albeit with some fluctuations (Fig. 2a), and COD removal at around $90 \%$ after three days of period C (Fig. 2b).

In order to gain more insight into the effects of changing the SBR operating conditions, colour degradation and COD removal during the 24 hour cycle were analysed at four selected points: at day 17 of period A, on which COD removal has stabilised, at day 24, immediately after changing from period $\mathrm{A}$ to $\mathrm{B}$, at day 39 of period $\mathrm{B}$ where the dye removal efficiency reached $80 \%$ and COD removal had stabilised around $50 \%$ and at day 73 of period $C$ where COD removal efficiency has increased to $90 \%$ in average while dye removal has stabilized at around 80\%. These data are presented in Figs. 3a-d and Figs. 4a-d.

In general, the majority of the dye removal occurred in the anaerobic phases, as also observed by Hakimelahi et al. (2012). Re-colourisation during the aerobic phase has also been observed in earlier work (Cruz and Buitron, 2001, Libra et al., 2004, Sponza and Işık, 2005) and has been explained by unstable aromatic amines being generated as a by-product of dye degradation under anaerobic conditions. These amines can easily oxidise and re-colour when exposed to oxygen during the aerobic phases. In addition, absorption of colour into the sludge biomass may also influence on the overall removal efficiency (Otero et al., 2003, Wang et al., 2006, Sirianuntapiboon and Srisornsak, 2007).

Early in the process (day 17) a pronounced re-colouration in the anaerobic phase was observed. Although dye removal efficiency reached $50 \%$ during the anaerobic phase, the efficiency declined during the aerobic phase resulting in an overall poor performance. At day 24, just after entering period B (with an increased anaerobic phase from 9 hours to 11 hours), re-colouration in the anaerobic phase was less pronounced, however, dye removal efficiency never exceeded $35 \%$. At day 39, after 15 days under period B conditions, dye removal efficiency increased to $43 \%$ at the end of the anaerobic phase, reaching almost $60 \%$ at the end of the aerobic phase. At day 73 of period $\mathrm{B}$ no re-colouration in the anaerobic phase was observed and the removal efficiency reached $65 \%$ before entering the aerobic phase. Despite a slight decrease, to about $60 \%$ at the end of the aerobic phase, the overall performance (reflected in the area under the curve) was optimal, demonstrating the feasibility of SBR-based dye degradation.

Figs. 4a-d are presenting the corresponding COD values during the 24 hour cycle. Generally, the COD measurements showed that the COD substantially reduced during the aerobic phase. The average removal efficiency at days 17,24 , and 73 were $34.7 \%, 63.9 \%$, and $56.8 \%$, respectively. This is consistent with the results of Asadi et al. (2012) who studied the effect of hydraulic retention time and aeration time on COD removal in a bioreactor. The efficiency at day 39 was only $4 \%$ which likely reflects the formation of inhibitory products within the microbial consortium. Thus, in conclusion, COD removal was the most efficient within period $\mathrm{C}$, concomitantly with the highest degree of dye removal.

Concomitantly with the changes of dye concentrations and COD reduction, we analysed the overall changes in biomass density and $\mathrm{pH}$ values. The results are presented in Figs. 5a-b. During the first ten days after the inoculation of the activated sludge, the biomass decreased 
slightly what is consistent with the fact that the micro-organisms were introduced into the system from an open tank with aerobic conditions, whereas in a closed system the alternating anaerobic and aerobic conditions were provided. In addition, temperature, composition of the nutritional broth, and $\mathrm{pH}$ values were different in our SBR system in comparison to the original ecological conditions from where the activated originated. After the lag phase, the sludge concentration increased up to day 34 (first part of period B) indicating the exponential growth phase of biomass. Between days 34 and 40 (second part of period B) the sludge concentration only increased very little. After day 40 the biomass was decaying, indicating the depletion of the nutrients in the medium, and the formation of inhibitory products. After entering period $\mathrm{C}$ during which the duration of the aerobic reaction phase was extended, the biomass concentration increased to around $11 \mathrm{~g} / \mathrm{L}$. Before biomass decrease in period $\mathrm{B}$, the $\mathrm{pH}$ values at the end of the anaerobic reaction phase and $\mathrm{pH}$ of the effluent dropped significantly. Finally, at the beginning of period $\mathrm{C}, \mathrm{pH}$ values were restored to values of period $\mathrm{A}$.

When comparing COD removal (Fig. 2b) with biomass growth in the SBR (Fig. 5a), one can observe that the COD removal was maximal during the exponential growth of micro-organisms (during period A). The decrease in COD removal efficiency in the effluent is evident after day 33 of period $\mathrm{B}$ and correlates with the observed effluent $\mathrm{pH}$ changes. The decrease in COD removal also manifested itself by changes in odour, higher turbidity, and lower settling ability. The results in Fig. 5b illustrate how the $\mathrm{pH}$ values of influent and effluent can be used as one of the indicators of a well-running SBR bioprocess. The $\mathrm{pH}$ values of the activated sludge were between 5.5 and 7.5 after the anaerobic reaction phase and between 8 and 9 at the end of the SBR cycle. During period B the $\mathrm{pH}$ values of effluent dropped from around 9 to below 6 at day 37 and COD removal efficiency was still 70\%. Two days later the COD removal efficiency dropped to around $42 \%$.

\subsection{UF treatment contribution on SBR effluent}

The effluent from the SBR was subjected to UF treatment. In order to assess the efficiency of the UF treatment two representative effluent samples were selected, one from day 33 of period $B$ where biodegradation was efficient in terms of COD removal and one from day 67 of period $\mathrm{C}$ where degradation efficiency was low. This allowed for evaluating the UF treatment as a counter-measure when the biological process as such is not efficient enough. The collected SBR effluent was first filtered through cellulose filter paper to prevent membrane fouling and afterwards passed on to the UF cell. The results of the treatments with SBR, UF, and the combined method are shown in Tables 4 and 5 where $\mathrm{R}_{\mathrm{E}}$ indicates the removal efficiency in \% (Eq. 1).

When the SBR was running efficiently (day 33) the UF treatment reduced effluent dye concentration almost tenfold. When the SBR degradation process in terms of COD removal was impaired (day 67), UF treatment reduced effluent dye concentration only by $40 \%$. As the colour is visible to the naked eye at concentrations as low as $1 \mathrm{mg} / \mathrm{L}$ (Öztekin, 2004), UF treatment is not in itself sufficient to obtain colourless effluent. However, UF treatment has the highest efficiency for colour removal when the SBR process is effective in terms of COD removal. The COD concentrations were also decreased by the UF treatment by approximately $41 \%$ at day 33 and by $48 \%$ at day 67 i.e. the effect of UF on COD removal was strongest when the SBR was working under less than optimal conditions. Still when the SBR was working well (day 33) the combined SBR+UF treatment resulted in dye and COD removal efficiencies of $96.6 \%$ and $94 \%$ respectively. 


\subsection{Characterisation of the SBR microbial consortium}

In order to gain insight into the SBR microbial composition, facultative aerobic microorganisms were isolated from the SBR sludge. The prevalent bacteria were Serratia marcescens, Klebsiella oxytoca, Elizabethkingia miricola, and Morganella morganii (presented in Table 6). Serratia sp., Klebsiella sp. and Morganella sp. are classified into the family Enterobacteriaceae. They are Gram-negative, facultative aerobic, oxidase negative bacteria. Many of them are part of the intestinal flora, and their typical habitats are soil and water. Their growth is stimulated at aerobic conditions, what happened also during the SBR process. Several studies have reported the strong ability of Klebsiella oxytoca to metabolise toxic compounds (Wong and Yuen, 1996, Kao et al., 2003). Klebsiella oxytoca isolated from cyanide containing wastewater was also able to use nitriles as the sole source of nitrogen (Kao et al., 2003). Wong and Yuen (Wong and Yuen, 1996) isolated five bacteria from dye contaminated sludge and found that Klebsiella sp. and $K$. pneumoniae showed decolourisation ability. The bacteria Morganella morganii also effectively decolourise and degrade the multi-sulphonated azo dye RB-B (Kitts et al., 1994) without formation of toxic metabolities. The bacteria identified in here presented work are therefore consistent with the results of previous studies. Besides the bacteria, two types of fungi, Trichosporon sp. $\left(1.5 \times 10^{3} \mathrm{CFU} / \mathrm{mL}\right)$ and Galactomyces $\mathrm{sp} .(2.5$ $\mathrm{x} 10^{3}-3.5 \times 10^{3} \mathrm{CFU} / \mathrm{mL}$ ) were also detected.

\subsubsection{The decolourisation ability of specific micro-organisms}

In order to assess the colour degrading ability of single isolates, we cultured individual microorganisms in nutrient broth containing acid azo dye $(60 \mathrm{mg} / \mathrm{L})$ under static conditions at room temperature. During the process the absorbance was followed (reflecting colour removal) (Fig. 6). Elizabethkingia miricola showed the highest rate - nearly $70 \%$ of decolourisation after 10 days of incubation. The decolourisation efficiency of Trichosporon sp., C. testosteroni and $M$. morganii were approximately $50 \%$. Galactomyces sp. decolourised wastewater by $14 \%$.

\section{Conclusions}

A stable microbial consortium was cultivated within a single SBR system with alternating anaerobic and aerobic reaction phases. The microbiota performed azo dye colour removal and COD reduction in a model azo day solution. After UF treatment of the SBR effluent, the removal efficiency was $94 \%$ for COD and $97 \%$ for the azo dye. In the SBR process, the predominant bacterial species were Serratia marcescens and Klebsiella oxytoca followed by Elizabethkingia miricola, Morganella morganii and Serratia sp. The microbial consortium also contained fungi Trichosporon sp. and Galactomyces sp. Our results demonstrated that the alternating anaerobic and aerobic SBR process combined with UF treatment can reach a high decolouration efficiency and COD reduction of azo dye containing wastewater.

\section{Acknowledgements}

The study was financed within the EraSME project titled "High-efficient and cost-effective air lift MBR for water reuse in textile finishing”, Project number 430-26/2010/40. 


\section{References}

AL-AMRANI, W. A., LIM, P.-E., SENG, C.-E. \& WAN NGAH, W. S. 2014. Factors affecting biodecolorization of azo dyes and COD removal in anoxic-aerobic REACT operated sequencing batch reactor. Journal of the Taiwan Institute of Chemical Engineers, 45, 609-616.

APHA (ed.) 2006. Standard Methods for the Examination of Water and Wastewater, Washington. DC, USA.

ASADI, A., ZINATIZADEH, A. A. L. \& HASNAIN ISA, M. 2012. Performance of intermittently aerated upflow sludge bed reactor and sequencing batch reactor treating industrial estate wastewater: $A$ comparative study. Bioresource Technology, 123, 495-506.

AYED, L., MAHDHI, A., CHEREF, A. \& BAKHROUF, A. 2011. Decolorization and degradation of azo dye Methyl Red by an isolated Sphingomonas paucimobilis: Biotoxicity and metabolites characterization. Desalination, 274, 272-277.

BRÁS, R., ISABEL A. FERRA, M., PINHEIRO, H. M. \& GONÇALVES, I. C. 2001. Batch tests for assessing decolourisation of azo dyes by methanogenic and mixed cultures. Journal of Biotechnology, 89, 155-162.

CHEN, H. 2006. Recent Advances in Azo Dye Degrading Enzyme Research. Current Protein and Peptide Science, 7, 101-111.

CHENGALROYEN, M. D. \& DABBS, E. R. 2013. The microbial degradation of azo dyes: minireview. World Journal of Microbiology and Biotechnology, 29, 389-399.

ÇıNAR, Ö., YAŞAR, S., KERTMEN, M., DEMIRÖZ, K., YIGIT, N. Ö. \& KITIS, M. 2008. Effect of cycle time on biodegradation of azo dye in sequencing batch reactor. Process Safety and Environmental Protection, 86, 455-460.

CRUZ, A. \& BUITRON, G. 2001. Biodegradation of disperse blue 79 using sequenced anaerobic/aerobic biofilters. Water Science and Technology 44, 159-166.

EVANGELISTA-BARRETO, N. S., ALBUQUERQUE, C. D., VIEIRA, R. H. S. F. \& CAMPOS-TAKAKI, G. M. 2009. Cometabolic Decolorization of the Reactive Azo Dye Orange II by Geobacillus stearothermophilus UCP 986. Textile Research Journal, 79, 1266-1273.

HAKIMELAHI, M., MOGHADDAM, M. \& HASHEMI, S. 2012. Biological treatment of wastewater containing an azo dye using mixed culture in alternating anaerobic/aerobic sequencing batch reactors. Biotechnology and Bioprocess Engineering, 17, 875-880.

$\mathrm{HAO}$, O. J., KIM, H. \& CHIANG, P.-C. 2000. Decolorization of Wastewater. Critical Reviews in Environmental Science and Technology, 30, 449-505.

HOSSEINI KOUPAIE, E., ALAVI MOGHADDAM, M. R. \& HASHEMI, S. H. 2011. Post-treatment of anaerobically degraded azo dye Acid Red 18 using aerobic moving bed biofilm process: Enhanced removal of aromatic amines. Journal of Hazardous Materials, 195, 147-154.

JADHAV, J. P., KALYANI, D. C., TELKE, A. A., PHUGARE, S. S. \& GOVINDWAR, S. P. 2010. Evaluation of the efficacy of a bacterial consortium for the removal of color, reduction of heavy metals, and toxicity from textile dye effluent. Bioresource Technology, 101, 165-173.

KAO, C. M., LIU, J. K., LOU, H. R., LIN, C. S. \& CHEN, S. C. 2003. Biotransformation of cyanide to methane and ammonia by Klebsiella oxytoca. Chemosphere, 50, 1055-1061.

KAPDAN, I. K. \& OZTEKIN, R. 2006. The effect of hydraulic residence time and initial COD concentration on color and COD removal performance of the anaerobic-aerobic SBR system. Journal of Hazardous Materials, 136, 896-901.

KHEHRA, M. S., SAINI, H. S., SHARMA, D. K., CHADHA, B. S. \& CHIMNI, S. S. 2006. Biodegradation of azo dye C.I. Acid Red 88 by an anoxic-aerobic sequential bioreactor. Dyes and Pigments, 70, 1-7.

KITTS, C. L., CUNNINGHAM, D. P. \& UNKEFER, P. J. 1994. Isolation of three hexahydro-1,3,5-trinitro1,3,5-triazine-degrading species of the family Enterobacteriaceae from nitramine explosivecontaminated soil. Applied and Environmental Microbiology, 60, 4608-4611.

LIBRA, J. A., BORCHERT, M., VIGELAHN, L. \& STORM, T. 2004. Two stage biological treatment of a diazo reactive textile dye and the fate of the dye metabolites. Chemosphere, 56, 167-180.

LOURENÇO, N. D., NOVAIS, J. M. \& PINHEIRO, H. M. 2000. Reactive textile dye colour removal in a sequencing batch reactor. Water Science and Technology, 42, 321-328.

LOURENÇO, N. D., NOVAIS, J. M. \& PINHEIRO, H. M. 2001. Effect of some operational parameters on textile dye biodegradation in a sequential batch reactor. Journal of Biotechnology, 89, 163174.

ONG, S.-A., TOORISAKA, E., HIRATA, M. \& HANO, T. 2005. Decolorization of azo dye (Orange II) in a sequential UASB-SBR system. Separation and Purification Technology, 42, 297-302. 
OTERO, M., ROZADA, F., CALVO, L. F., GARCíA, A. I. \& MORÁN, A. 2003. Kinetic and equilibrium modelling of the methylene blue removal from solution by adsorbent materials produced from sewage sludges. Biochemical Engineering Journal, 15, 59-68.

ÖZTEKIN, R. 2004. Colour removal from textile wastewater in sequencing batch reactor. Dokuz Eylül University.

PANSWAD, T., TECHOVANICH, A. \& ANOTAI, J. 2001. Comparison of dye wastewater treatment by normal and anoxic + anaerobic/aerobic SBR activated sludge processes. Water science and technology : a journal of the International Association on Water Pollution Research, 43, 355362.

PHUGARE, S. S., KALYANI, D. C., SURWASE, S. N. \& JADHAV, J. P. 2011. Ecofriendly degradation, decolorization and detoxification of textile effluent by a developed bacterial consortium. Ecotoxicology and Environmental Safety, 74, 1288-1296.

RAJAGURU, P., KALAISELVI, K., PALANIVEL, M. \& SUBBURAM, V. 2000. Biodegradation of azo dyes in a sequential anaerobic-aerobic system. Applied Microbiology and Biotechnology, 54, 268273.

SANI, R. K. \& BANERJEE, U. C. 1999. Decolorization of triphenylmethane dyes and textile and dyestuff effluent by Kurthia sp. Enzyme and Microbial Technology, 24, 433-437.

SARATALE, R. G., SARATALE, G. D., CHANG, J. S. \& GOVINDWAR, S. P. 2011. Bacterial decolorization and degradation of azo dyes: A review. Journal of the Taiwan Institute of Chemical Engineers, 42, 138-157.

SIRIANUNTAPIBOON, S. \& SRISORNSAK, P. 2007. Removal of disperse dyes from textile wastewater using bio-sludge. Bioresource Technology, 98, 1057-1066.

SLAPŠAK, N., CLEENWERCK, I., DE VOS, P. \& TRČEK, J. 2013. Gluconacetobacter maltaceti, a novel vinegar producing acetic acid bacterium. Systematic and Applied Microbiology, 36, 17-21.

SOLÍS, M., SOLÍS, A., PEREZ, H. I., MANJARREZ, N. \& FLORES, M. 2012. Microbial decolouration of azo dyes: A review. Process Biochemistry, 47, 1723-1748.

SPONZA, D. T. \& IŞIK, M. 2002. Decolorization and azo dye degradation by anaerobic/aerobic sequential process. Enzyme and Microbial Technology, 31, 102-110.

SPONZA, D. T. \& IŞıK, M. 2005. Reactor performances and fate of aromatic amines through decolorization of Direct Black 38 dye under anaerobic/aerobic sequentials. Process Biochemistry, 40, 35-44.

ŠTORNIK, A., SKOK, B. \& TRČEK, J. 2016. Comparison of cultivable acetic acid bacterial microbiota in organic and conventional apple cider vinegar. Food Technology and Biotechnology, 54, 113119.

WANG, Y., MU, Y., ZHAO, Q.-B. \& YU, H.-Q. 2006. Isotherms, kinetics and thermodynamics of dye biosorption by anaerobic sludge. Separation and Purification Technology, 50, 1-7.

WONG, P. K. \& YUEN, P. Y. 1996. Decolorization and biodegradation of methyl red by Klebsiella pneumoniae RS-13. Water Research, 30, 1736-1744.

WU, Y., LI, T. \& YANG, L. 2012. Mechanisms of removing pollutants from aqueous solutions by microorganisms and their aggregates: A review. Bioresource Technology, 107, 10-18.

ZURIAGA-AGUSTÍ, E., IBORRA-CLAR, M. I., MENDOZA-ROCA, J. A., TANCREDI, M., ALCAINAMIRANDA, M. I. \& IBORRA-CLAR, A. 2010. Sequencing batch reactor technology coupled with nanofiltration for textile wastewater reclamation. Chemical Engineering Journal, 161, 122-128. 


\section{List of figures}

Fig. 1. UV/VIS spectrum of Nylosan yellow E2RL SGR.

Fig. 2. Colour and COD removal efficiency: (a) colour concentration in the SBR effluent, (b) COD removal efficiency.

Fig. 3. Dye removal efficiency in samples taken within the 24-hour SBR cycle: (a) at day 17; (b) at day 25; (c) at day 39; (d) at day 73.

Fig. 4. COD removal efficiency measured in samples taken within the 24-hour SBR cycle: (a) at day 17; (b) at day 25; (c) at day 39; (d) at day and 73.

Fig. 5. a) Biomass growth in the SBR; (b) $\mathrm{pH}$ values in the influent, during anoxic phase, and in the effluent.

Fig. 6. Decolourization rate of specific microorganisms. 
Table 1 The composition of the synthetic wastewater (influent to the SBR).

\begin{tabular}{lccc}
\hline $\begin{array}{l}\text { Operating } \\
\text { day }\end{array}$ & $\begin{array}{c}\text { Azo dye concentration } \\
(\mathbf{m g} / \mathbf{L})\end{array}$ & $\begin{array}{c}\text { Nutrient broth } \\
\text { concentration }(\mathbf{g} / \mathbf{L})\end{array}$ & $\begin{array}{c}\text { D-glucose } \\
\text { concentration } \\
(\mathbf{m g} / \mathbf{L})\end{array}$ \\
\hline $1-21$ & 20 linearly increasing to 80 & 13 & 4 linearly increasing \\
to 8 \\
$22-100$ & 60 & 6.5 & 8 \\
\hline
\end{tabular}


Table 2 UF membrane specifications.

\begin{tabular}{ll}
\hline Parameter & \\
\hline Material & Polyarcylonitrile (PAN) \\
\hline $\begin{array}{l}\text { MWCO (molecular weight cut off) } \\
(\mathrm{kDa})\end{array}$ & $100-200$ \\
\hline $\mathrm{pH}$ & $2-10$ \\
\hline Contact angle & $61.33-59.30$ \\
\hline Zeta Potential $(\mathrm{mV})$ & -73 \\
\hline Isoelectric $\mathrm{pH}$ & 2.9 \\
\hline
\end{tabular}


Table 3 SBR operating conditions.

\begin{tabular}{cccccccc}
\hline Period & Day & $\begin{array}{c}\text { Filling } \\
\text { (min) }\end{array}$ & $\begin{array}{c}\text { Anaerobic } \\
\text { phase (h) }\end{array}$ & $\begin{array}{c}\text { Aerobic } \\
\text { phase(h) }\end{array}$ & $\begin{array}{c}\text { Settling } \\
\text { phase (h) }\end{array}$ & $\begin{array}{c}\text { Drawing } \\
\text { phase (min) }\end{array}$ & $\begin{array}{c}\text { Idling } \\
\text { phase (min) }\end{array}$ \\
\hline A & $1-24$ & 5 & 9 & 12 & 2.5 & 10 & 15 \\
\hline B & $24-58$ & 5 & 11 & 11 & 1.5 & 10 & 15 \\
\hline C & $58-100$ & 5 & 9 & 13 & 1.5 & 10 & 15 \\
\hline
\end{tabular}


Table 4 The results for dye removal from wastewater by SBR, UF, and the combined method of SBR and UF.

\begin{tabular}{cccccc}
\hline $\begin{array}{c}\text { Operational } \\
\text { day }\end{array}$ & $\begin{array}{c}\text { Dye in influent } \\
(\mathrm{mg} / \mathrm{L})\end{array}$ & $\begin{array}{c}\text { Dye in SBR } \\
\text { effluent }(\mathrm{mg} / \mathrm{L})\end{array}$ & $\begin{array}{c}\mathrm{R}_{\mathrm{E}} \text { of the } \\
\text { SBR }(\%)\end{array}$ & $\begin{array}{c}\text { Dye in UF } \\
\text { effluent }(\mathrm{mg} / \mathrm{L})\end{array}$ & $\begin{array}{c}\mathrm{R}_{\mathrm{E}} \text { of combined } \\
\text { method }(\%)\end{array}$ \\
\hline 33 & 69.93 & 21.18 & 69.71 & 2.43 & 96.6 \\
\hline 67 & 68.61 & 14.44 & 78.96 & 10.42 & 86.8 \\
\hline
\end{tabular}


Table 5 The results for COD removal from wastewater by SBR, UF, and the combined method of SBR and UF

\begin{tabular}{cccccc}
\hline $\begin{array}{c}\text { Operational } \\
\text { day }\end{array}$ & $\begin{array}{c}\mathrm{COD} \text { in influent } \\
\left(\mathrm{mgO}_{2} / \mathrm{L}\right)\end{array}$ & $\begin{array}{c}\mathrm{COD} \text { in SBR } \\
\text { effluent }\left(\mathrm{mgO}_{2} / \mathrm{L}\right)\end{array}$ & $\begin{array}{c}\mathrm{R}_{\mathrm{E}} \text { of the } \\
\mathrm{SBR}(\%)\end{array}$ & $\begin{array}{c}\mathrm{COD} \text { in UF } \\
\text { effluent }\left(\mathrm{mgO}_{2} / \mathrm{L}\right)\end{array}$ & $\begin{array}{c}\mathrm{R}_{\mathrm{E}} \text { of combined } \\
\text { method }(\%)\end{array}$ \\
\hline 33 & 10,473 & 1,057 & 89.91 & 628 & 94.0 \\
\hline 67 & 10,473 & 3,692 & 64.75 & 1,919 & 81.7 \\
\hline
\end{tabular}


Table 6 Number of different morphological types within the activated sludge from the bioprocess, and identification based on comparisons between sequences of $16 \mathrm{~S}$ rRNA genes.

\begin{tabular}{|c|c|c|}
\hline $\begin{array}{c}\text { CFU/mL after } \\
\text { anaerobic phase }\end{array}$ & $\begin{array}{c}\text { CFU/mL after } \\
\text { aerobic phase }\end{array}$ & $\begin{array}{c}\text { Identification by 16S } \\
\text { rRNA sequence analysis }\end{array}$ \\
\hline $8,9 \times 10^{5}$ & $9,5 \times 10^{5}$ & Serratia marcescens \\
\hline $3,2 \times 10^{5}$ & $7,1 \times 10^{5}$ & Klebsiella oxytoca \\
\hline $2,5 \times 10^{5}$ & $3,5 \times 10^{5}$ & Elizabethkingia $\mathrm{sp}$. \\
\hline $1,5 \times 10^{5}$ & $3,2 \times 10^{5}$ & Morganella morganii \\
\hline $3,8 \times 10^{5}$ & $1,7 \times 10^{5}$ & Serratia sp. \\
\hline 0 & $1 \times 10^{5}$ & Serratia sp. \\
\hline $2,5 \times 10^{5}$ & 0 & Serratia $\mathrm{sp}$. \\
\hline $1,5 \times 10^{3}$ & $1,510^{3}$ & Trichosporon $\mathrm{sp}$. \\
\hline $2,510^{3}$ & $3,510^{3}$ & Galactomyces $\mathrm{sp}$. \\
\hline
\end{tabular}




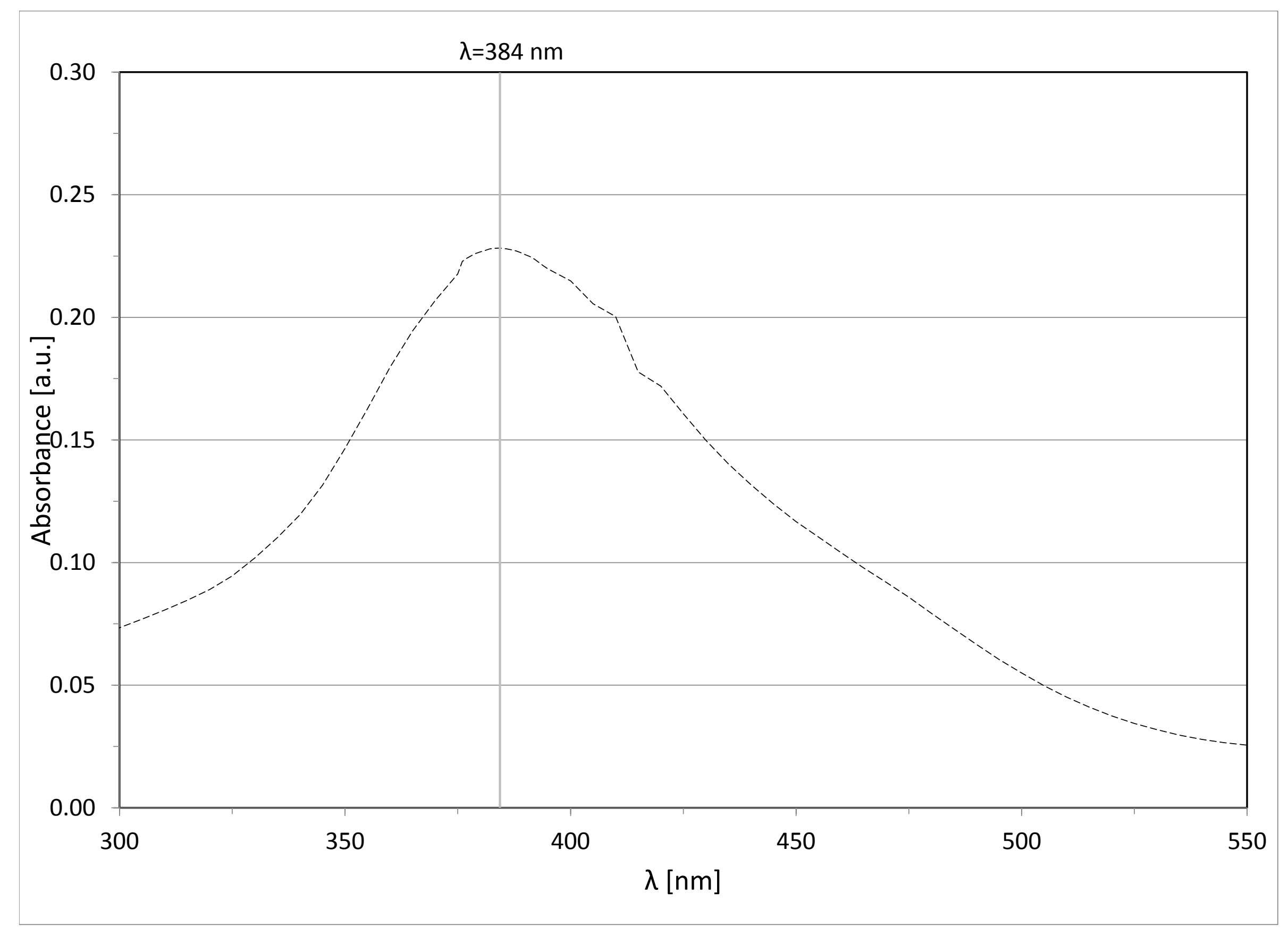




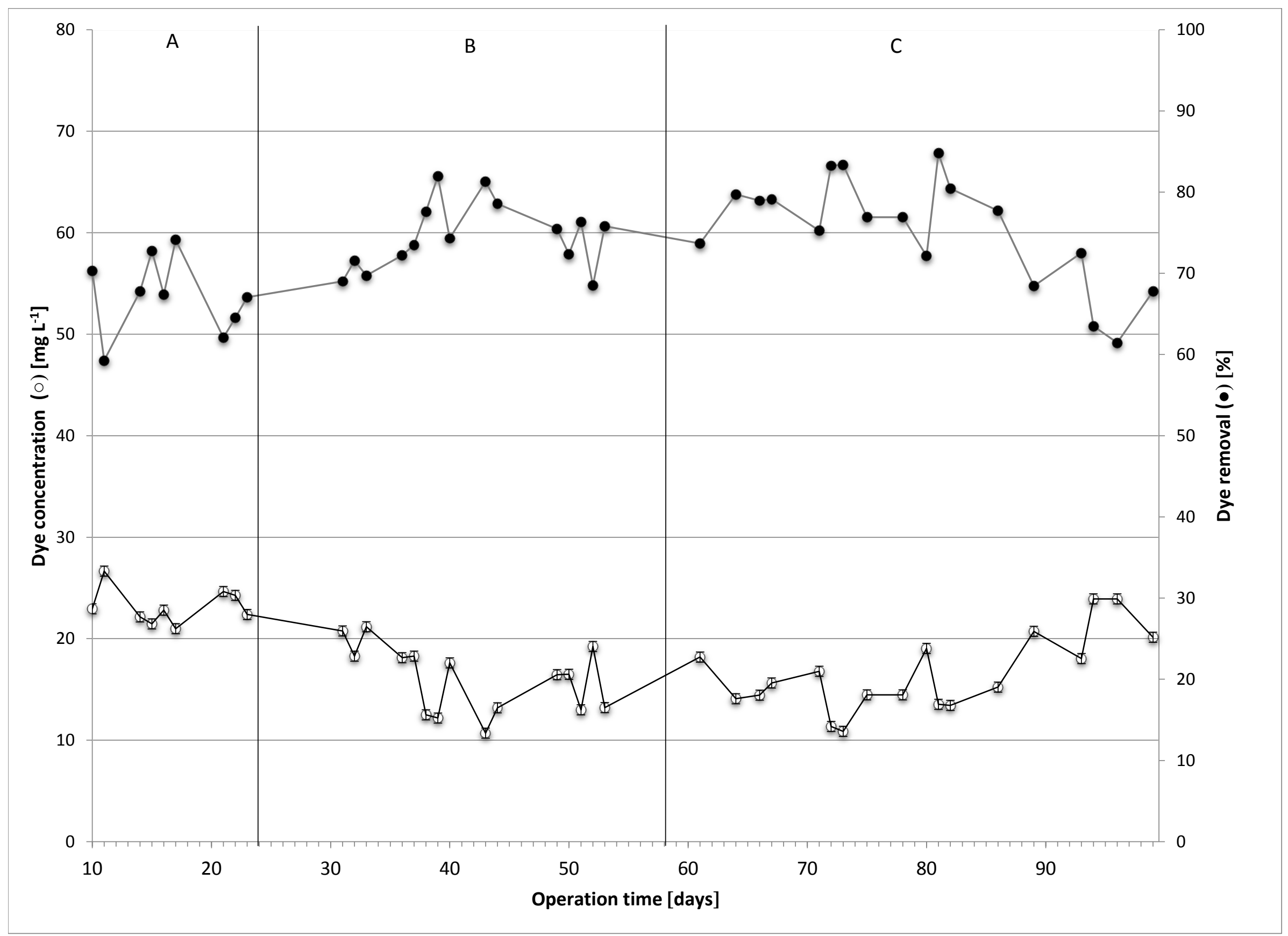




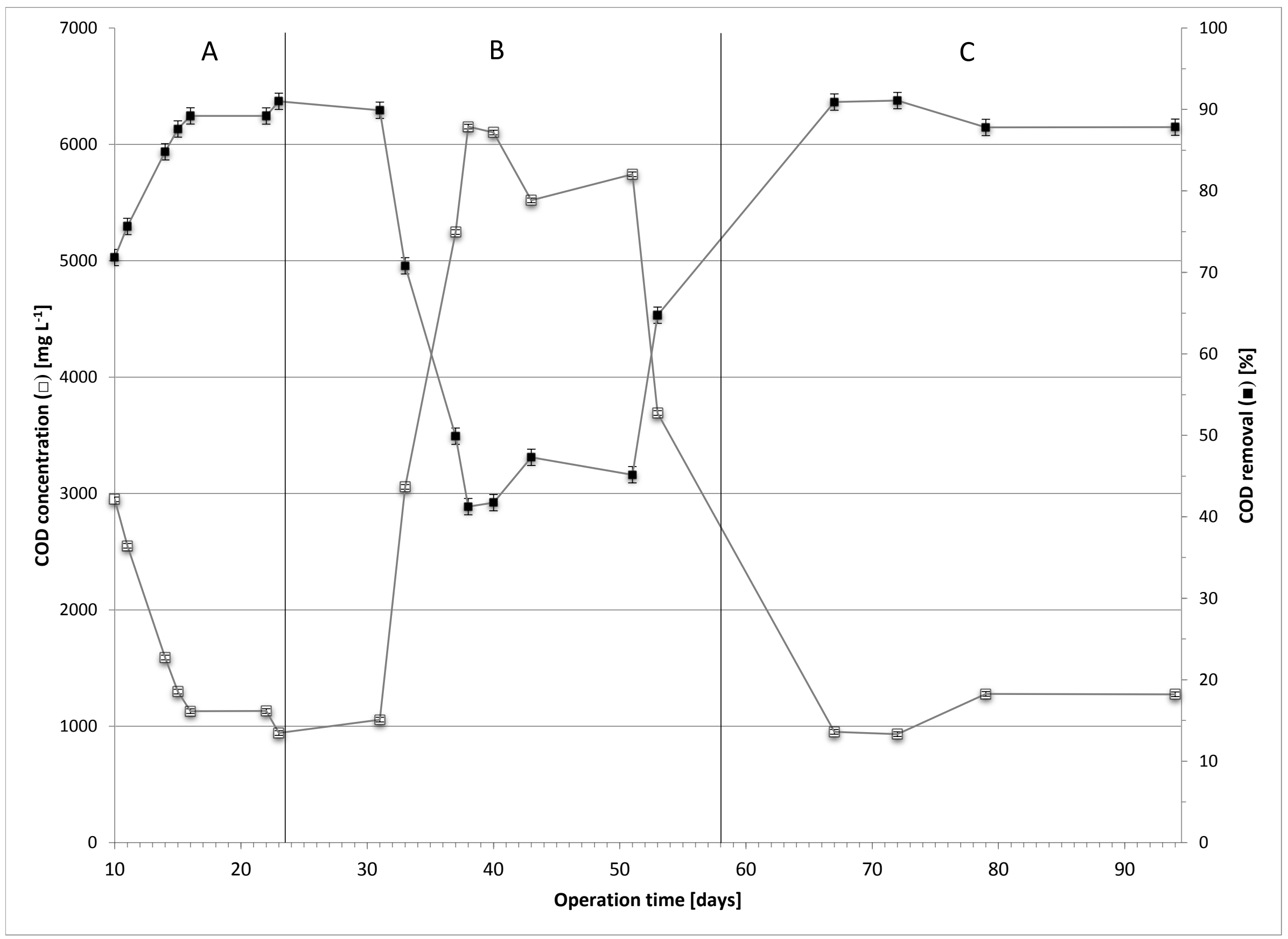




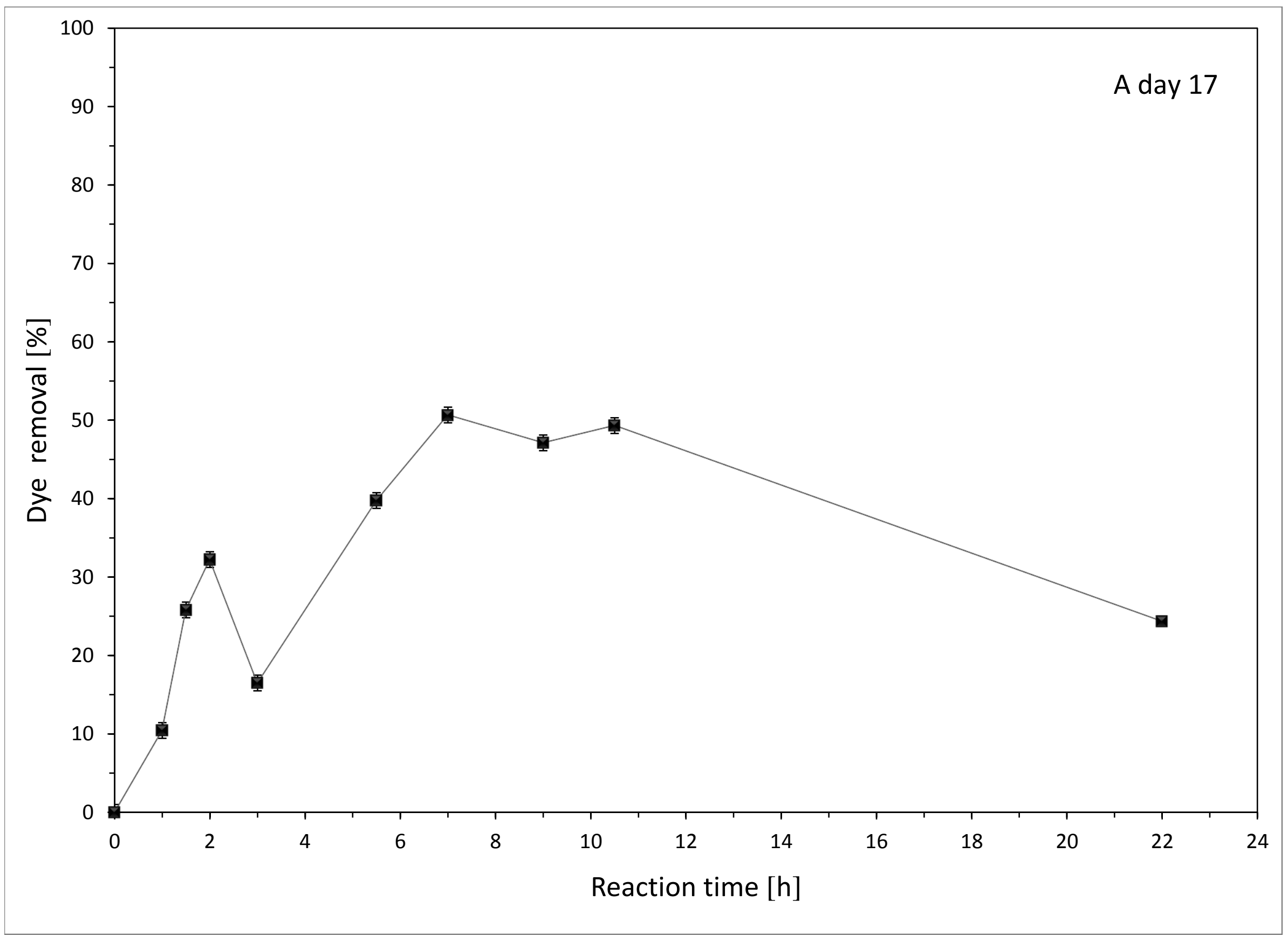




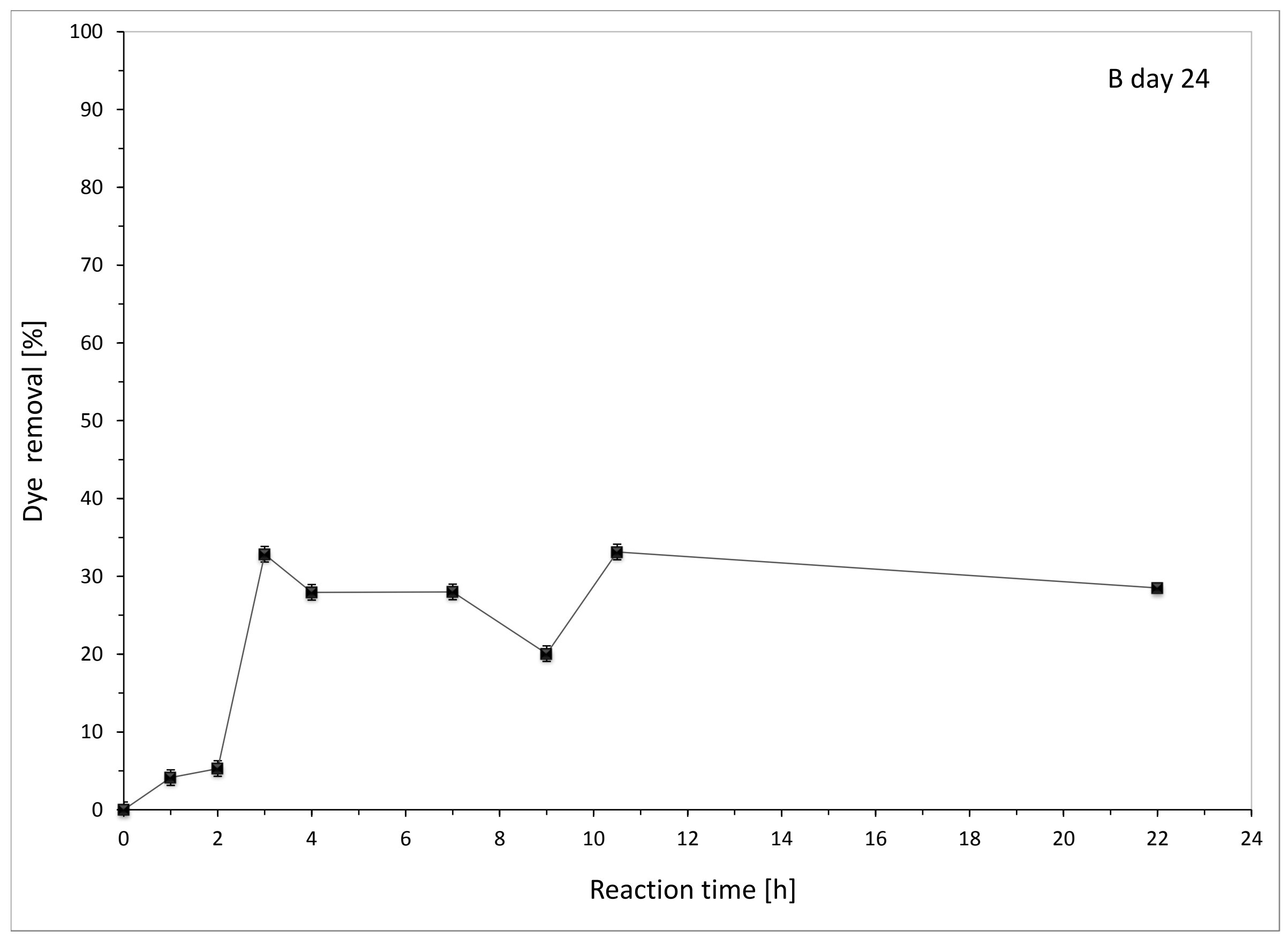




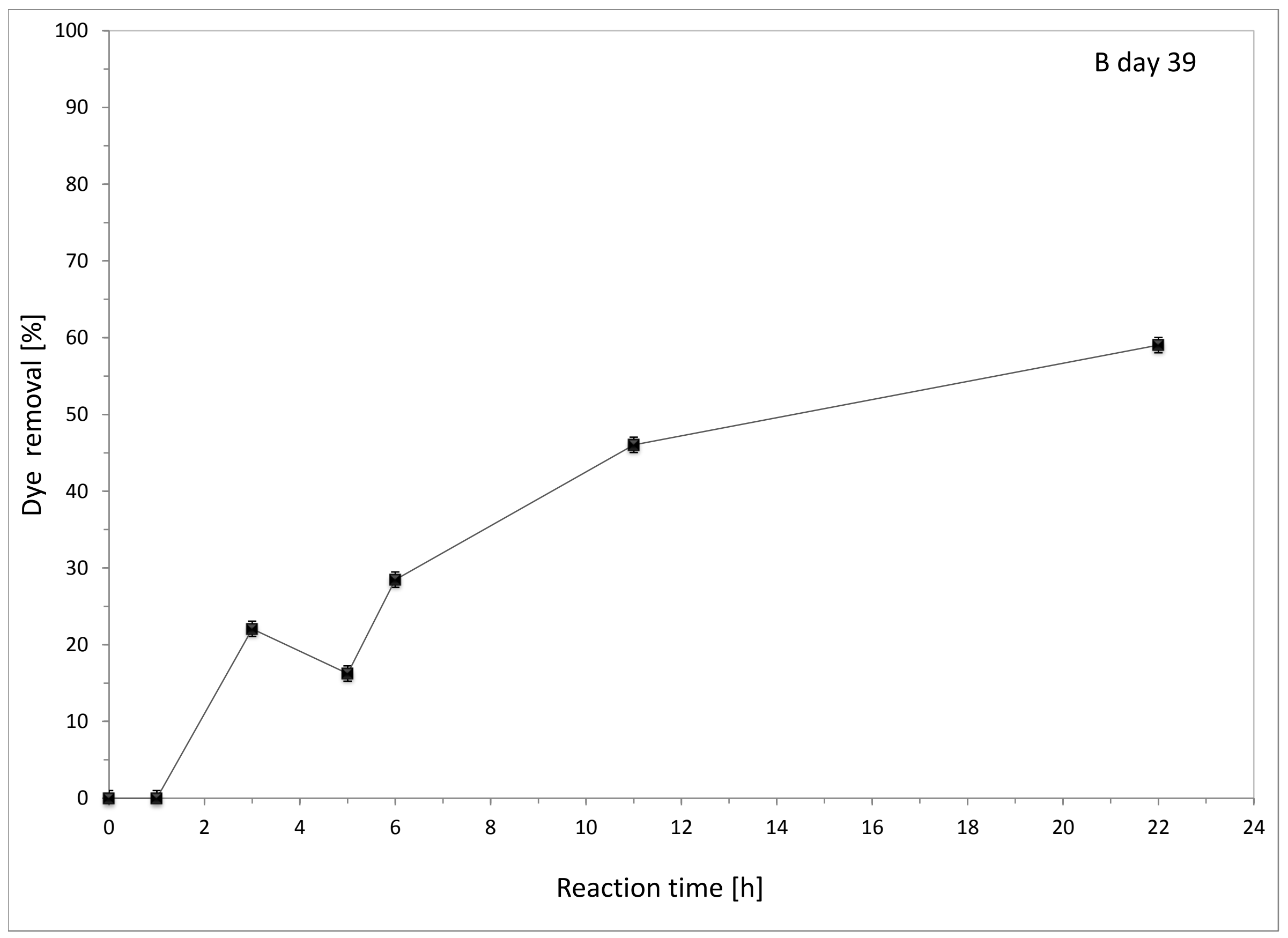




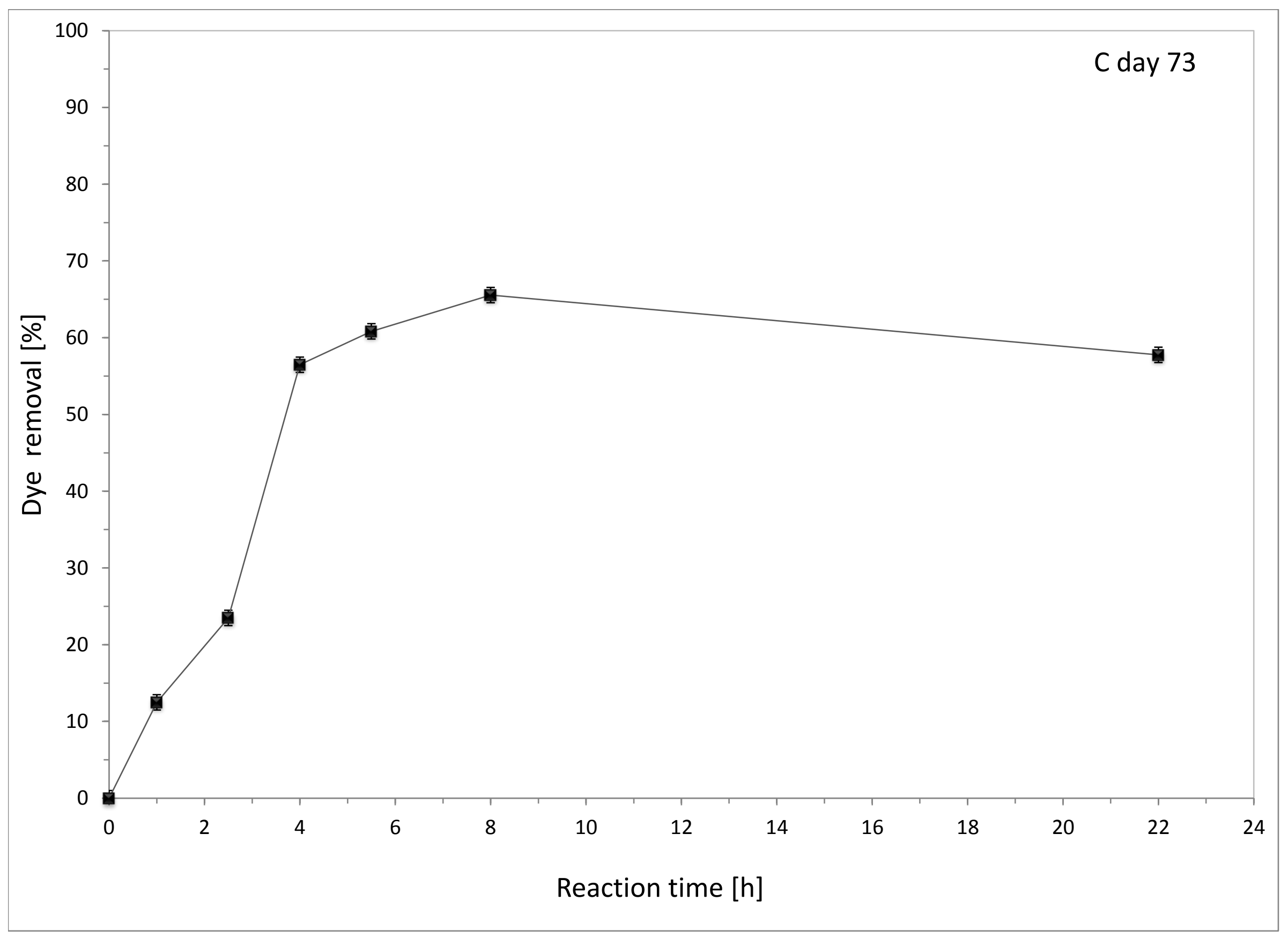




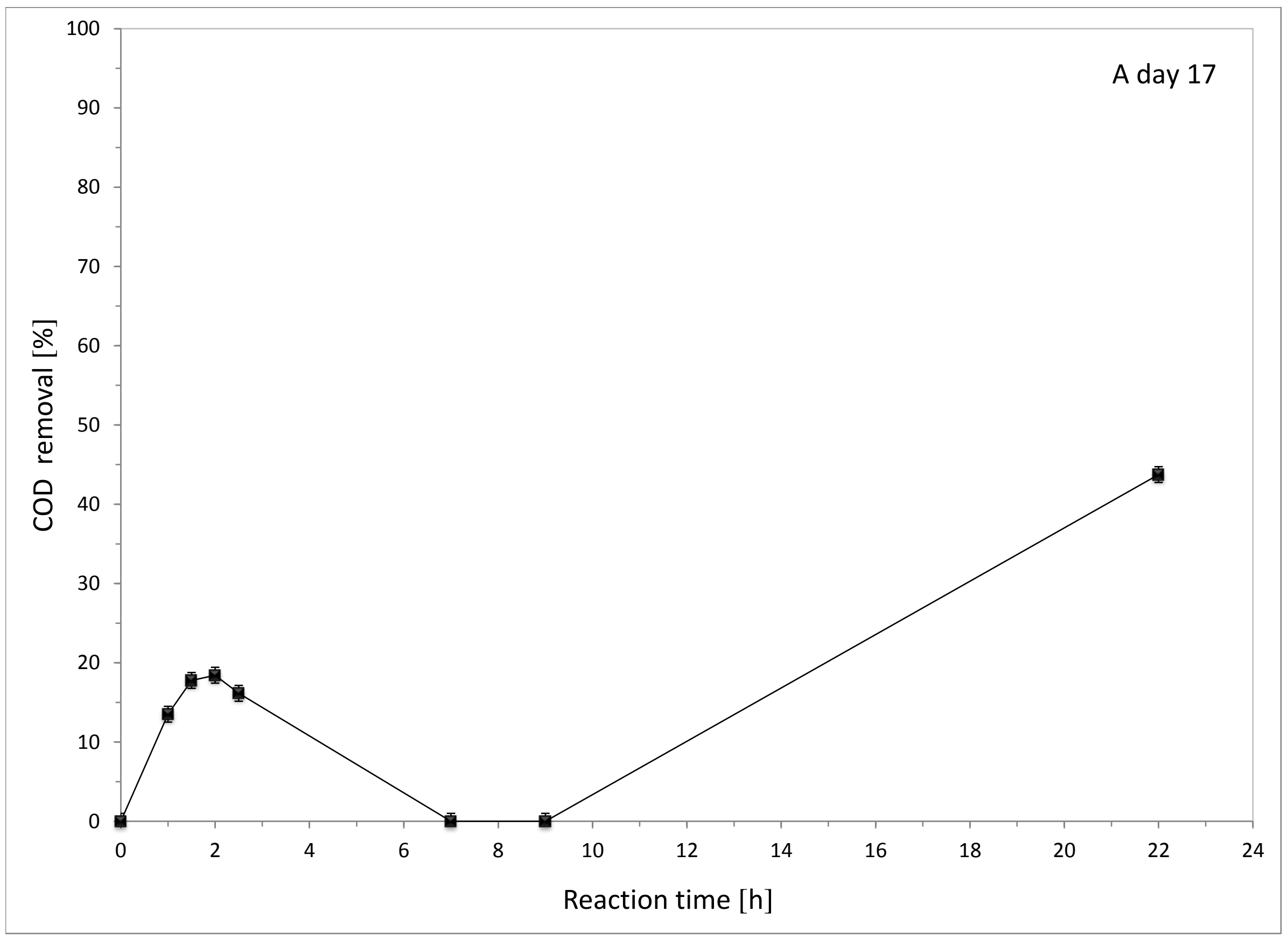




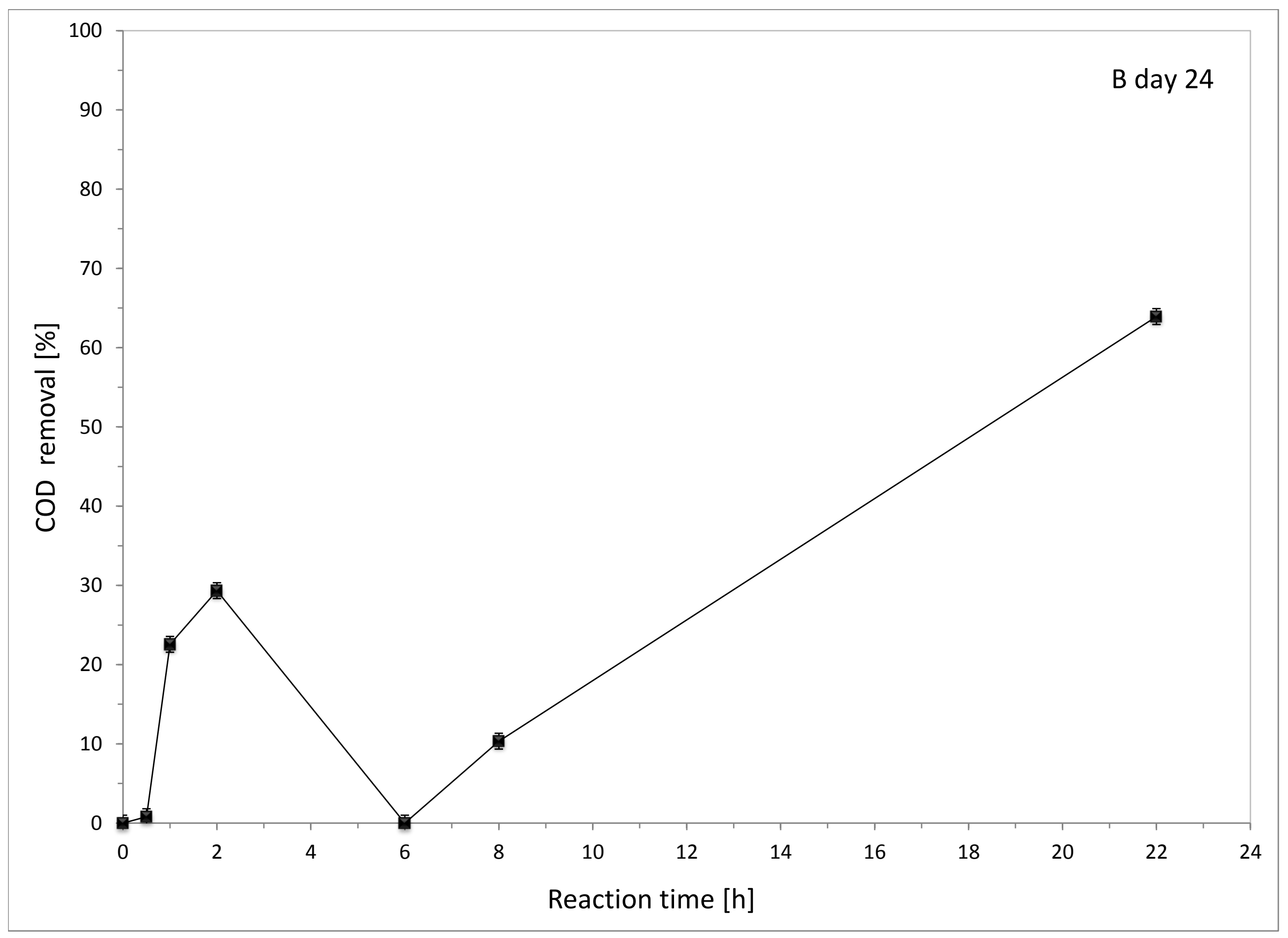




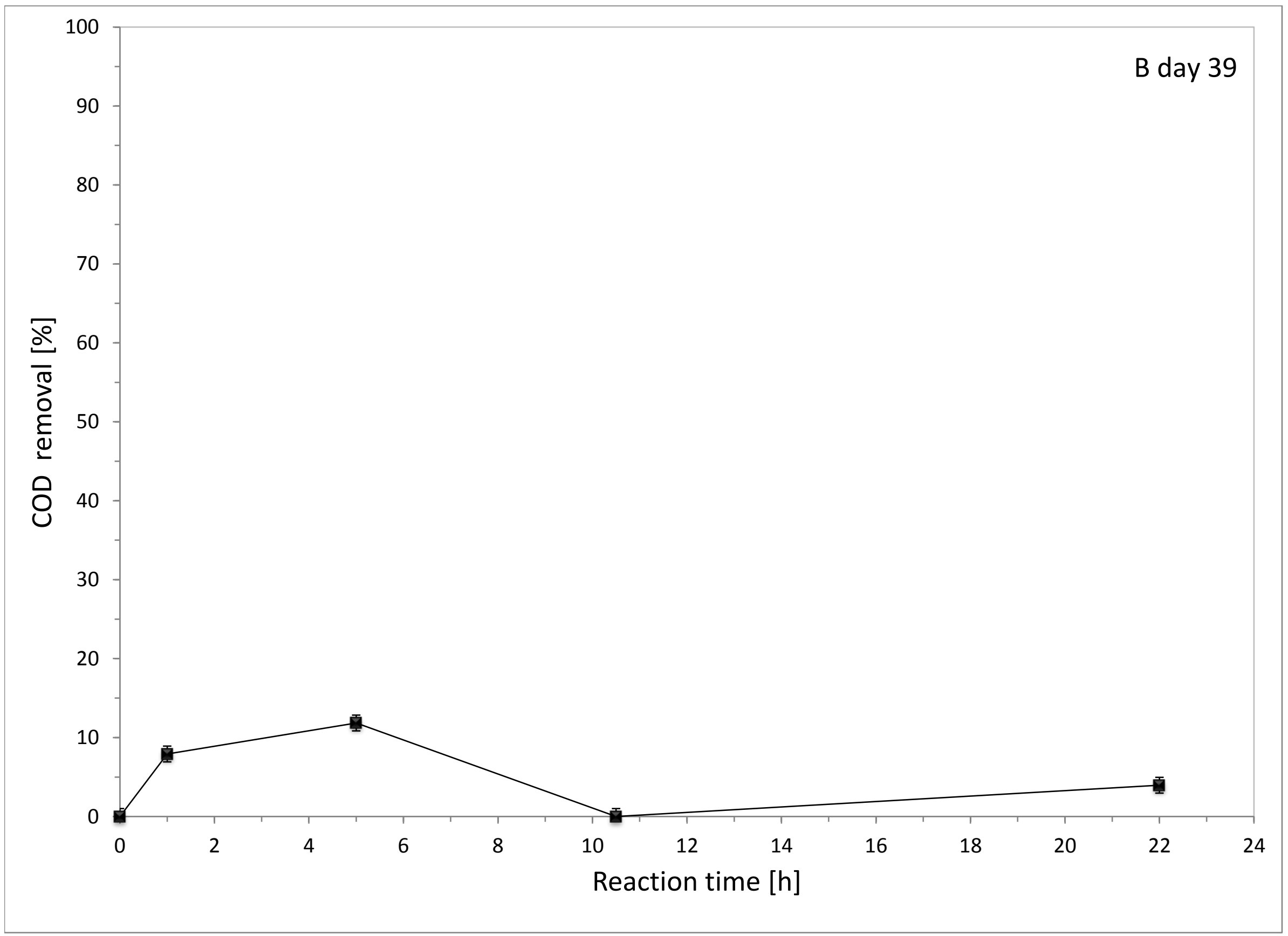




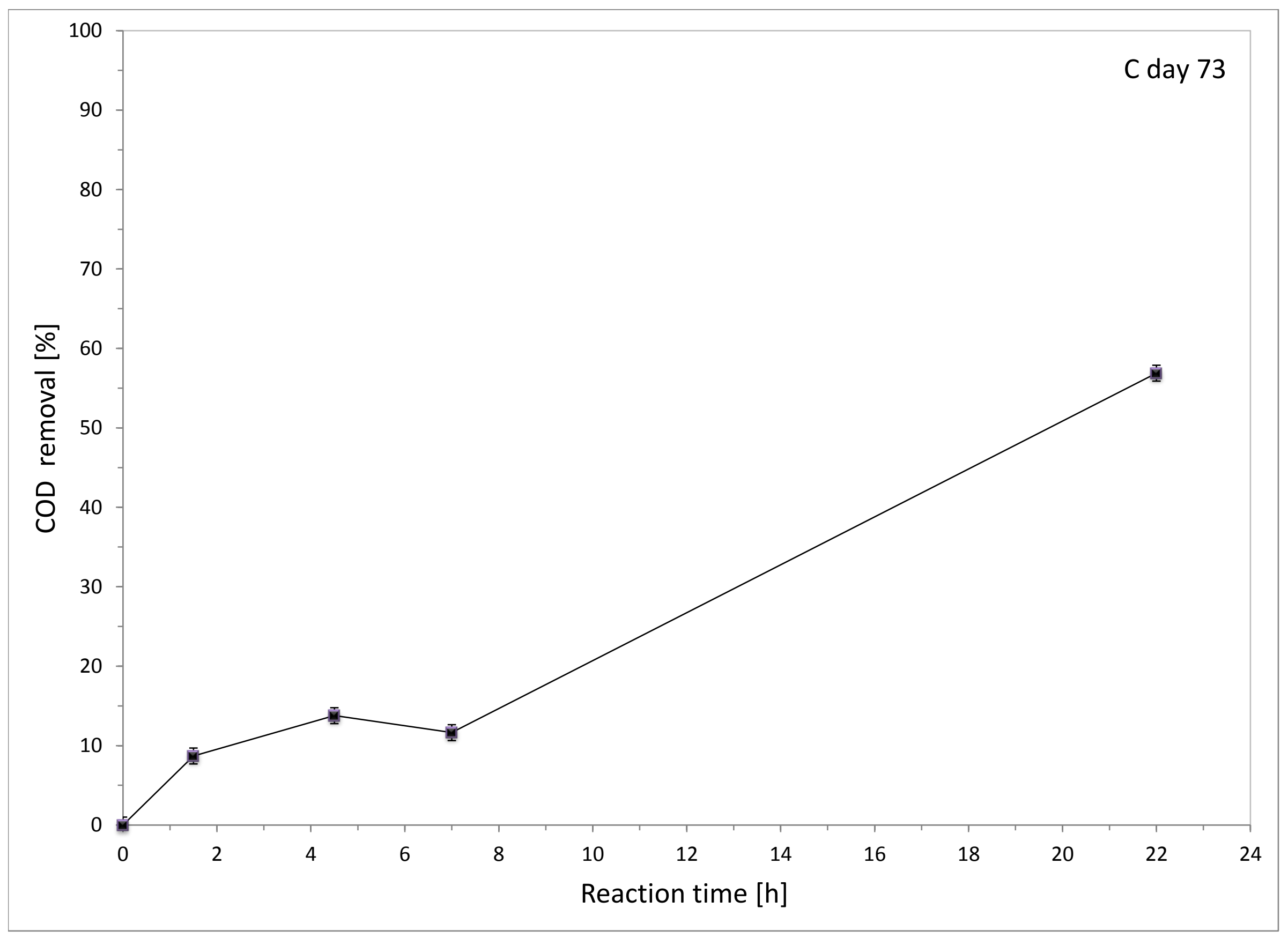




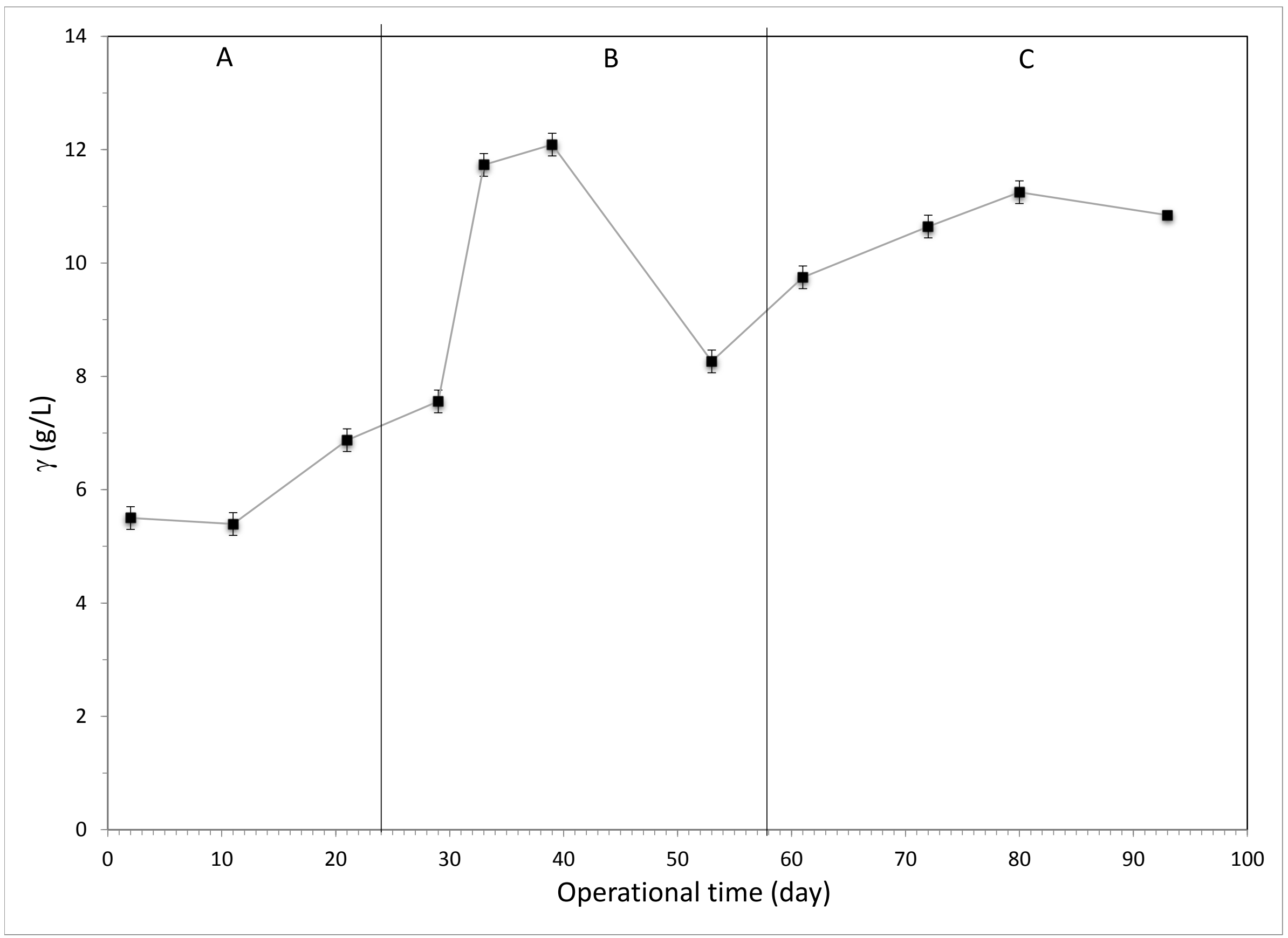




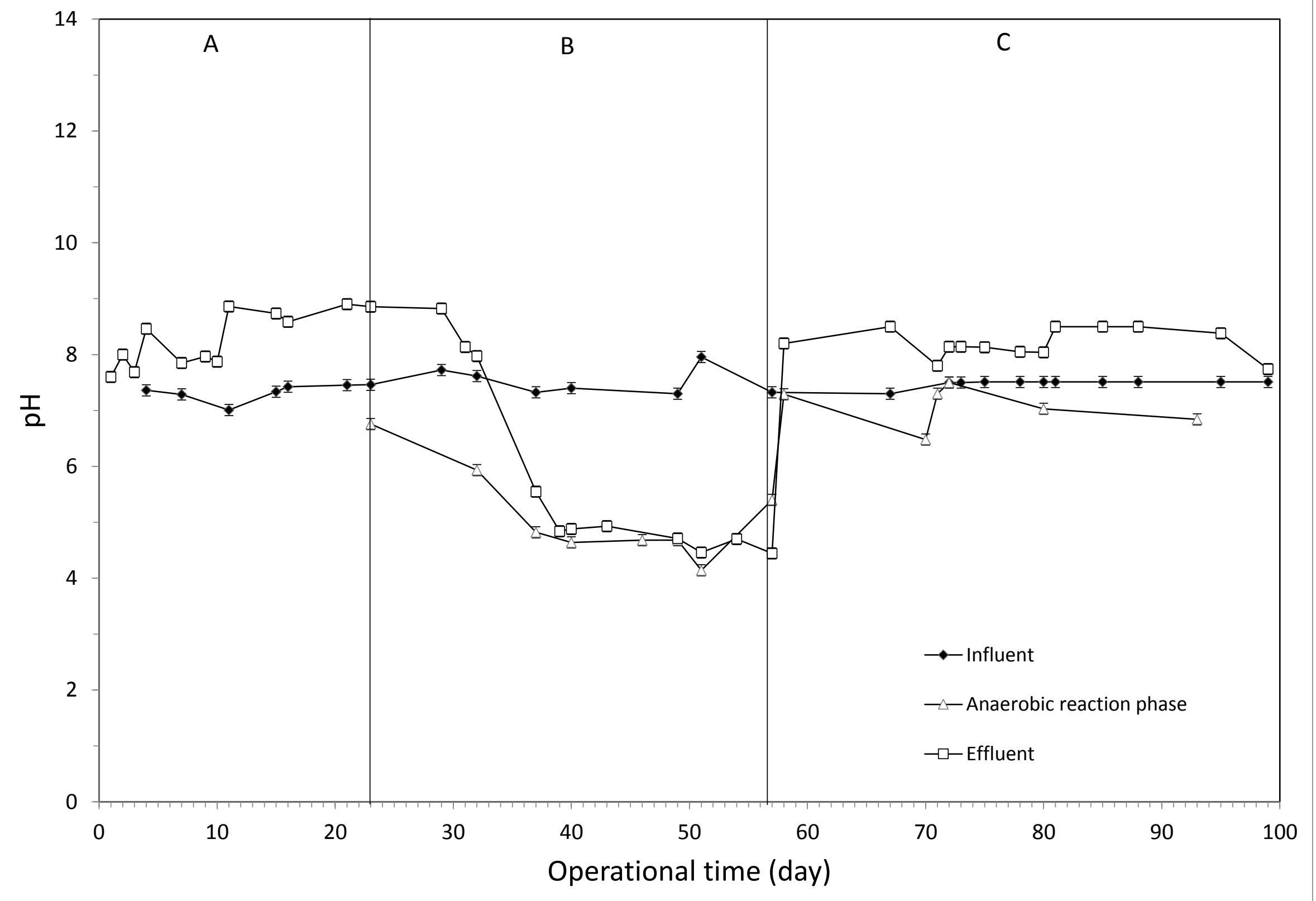




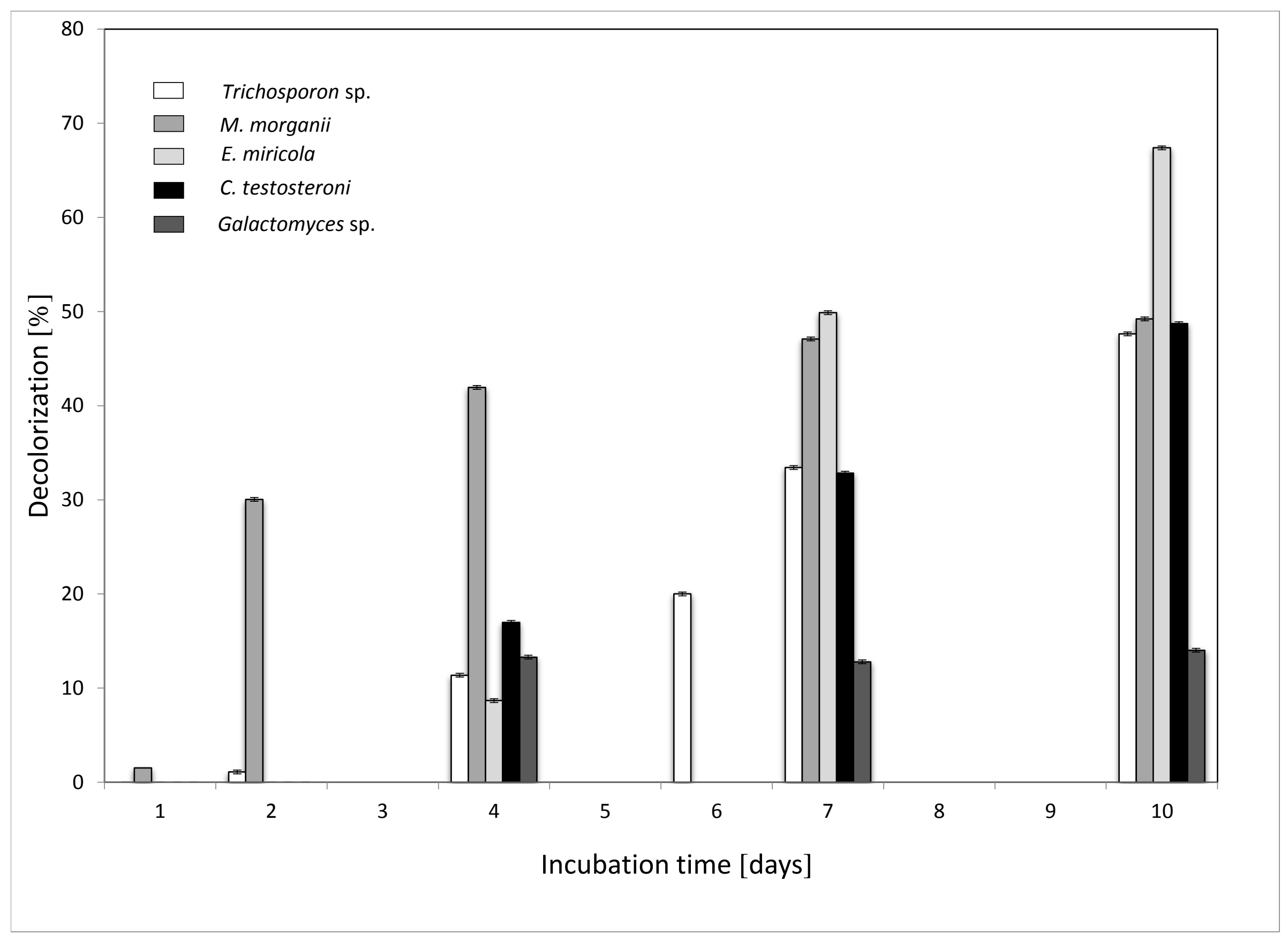

